\title{
Meta-analysis of the effects of prepartum dietary cation-anion difference on performance and health of dairy cows
}

\author{
J. E. P. Santos, ${ }^{1,2 *}$ I. J. Lean, ${ }^{3}$ H. Golder, ${ }^{3}$ and E. Block ${ }^{4}$ \\ ${ }^{1}$ Department of Animal Sciences, University of Florida, Gainesville 32611 \\ ${ }^{2} \mathrm{DH}$ Barron Reproductive and Perinatal Biology Research Program, University of Florida, Gainesville 32611 \\ ${ }^{3}$ Scibus, Camden, NSW, Australia 2570 \\ ${ }^{4}$ Arm \& Hammer Animal Nutrition, Princeton, NJ 08543
}

\section{ABSTRACT}

The objectives were to use meta-analytic methods to determine the effects of changes in dietary cation-anion difference (DCAD) prepartum on productive performance and health of dairy cows. The literature was systematically reviewed, searching randomized experiments with transition cows that manipulated the prepartum DCAD or experiments with acidogenic diets in which dietary $\mathrm{Ca}, \mathrm{P}$, or $\mathrm{Mg}$ was manipulated. Forty-two experiments, including 134 treatment means and 1,803 cows, were included in the meta-analysis. Of those, 5 experiments with 15 treatment means reported responses for 151 nulliparous cows. Data collected included the mineral composition of prepartum diets, parity group prepartum, breed, days on treatment, and means and respective measure of variance for urine $\mathrm{pH}$, dry matter intake (DMI), body weight, body condition, productive performance, concentrations of minerals and metabolites in blood, and incidence of diseases. Mixed effects meta-analyses were conducted weighting by the inverse of standard error of the means squared to account for the precision of each experiment. Models include the effects of DCAD, parity group prepartum, interaction between DCAD and parity group, and other covariates that showed significance in univariable analysis. Final models were selected based on parsimony and model fit. Reducing the prepartum DCAD reduced intake prepartum but improved intake postpartum in both parity groups. Interactions between DCAD and parity group occurred for yields of milk, fat-corrected milk (FCM), fat, and protein because reducing the DCAD improved those responses in parous cows; however, reducing the DCAD either had no effect on yields of milk and protein or reduced the yield of FCM and fat in nulliparous cows. The resulting equations from the statistical mod-

Received February 22, 2018.

Accepted October 26, 2018.

*Corresponding author: jepsantos@ufl.edu els predicted that reducing the DCAD from +200 to $-100 \mathrm{mEq} / \mathrm{kg}$ would increase blood total Ca on the day of calving from 1.86 to $2.04 \pm 0.05 \mathrm{mM}$, DMI postpartum $1.0 \mathrm{~kg} / \mathrm{d}$, and milk yield $1.7 \mathrm{~kg} / \mathrm{d}$ in parous cows. The increased concentrations of blood total Ca at calving and postpartum explained the marked reduction in risk of milk fever in parous cows with a reduction in DCAD. As the DCAD decreased, the risk of retained placenta and metritis also decreased, resulting in fewer disease events per cow in both nulliparous and parous cows. Dietary concentrations of $\mathrm{Ca}, \mathrm{P}$, or $\mathrm{Mg}$ prepartum had no effect on DMI or yields of milk and FCM; however, increasing dietary $\mathrm{Ca}$ within the study range of 0.16 to $1.98 \%$ of dry matter tended to increase the risk of milk fever in parous cows regardless of DCAD fed. Collectively, results support the recommendation of prepartum acidogenic diets to result in a negative DCAD to parous cows with improvements in lactation performance and reduced risk of diseases; however, the range of DCAD fed did not allow for detection of an optimum value for postpartum performance. On the other hand, despite improvements in blood concentrations of $\mathrm{Ca}$ and reduction in uterine diseases with a reduction in DCAD fed to nulliparous cows, productive performance was either depressed or unaffected and the limited number of experiments did not provide sufficient evidence for a recommended DCAD for this group of cows.

Key words: DCAD, health, meta-analysis, transition cow

\section{INTRODUCTION}

Manipulation of diet composition prepartum can have long-lasting effects on the subsequent lactation. In general, dry cows are fed diets to meet the nutrient needs of the dam and offspring while avoiding excessive nutrient intake to minimize body fat gain (Drackley, 1999). On the other hand, cows in the last 3 wk of gestation are fed diets to meet their nutrient needs, but these same diets are formulated with the aim of 
minimizing the risk of peripartum metabolic disorders (Drackley, 1999; Drackley and Cardoso, 2014; Lean et al., 2014). One such intervention is the manipulation of concentrations of strong ions in the diet to alter the prepartum DCAD. It has been well documented that feeding acidogenic diets prepartum reduces the risk of milk fever at the onset of lactation (Ender et al., 1971; Dishington, 1975; Block, 1984). In fact, extensive systematic reviews have clearly documented that reducing the DCAD of prepartum diets by inclusion of acidogenic salts or products improves concentrations of $\mathrm{Ca}$ in blood at calving and reduces the incidence of milk fever (Oetzel, 1991; Charbonneau et al., 2006; Lean et al., 2006).

The objective of feeding prepartum cows acidogenic diets is to induce a compensated metabolic acidosis that improves the ability of cows to maintain increased blood $\mathrm{Ca}$ when synthesis of colostrum and milk occurs (Charbonneau et al., 2006; Lean et al., 2006). Metabolism of $\mathrm{Ca}$ and other minerals, such as $\mathrm{P}$ and $\mathrm{Mg}$, is interrelated, and the onset of lactation results in a transient period of hypocalcemia because of the irreversible loss of $\mathrm{Ca}$ in colostrum and milk (Ramberg et al., 1970). Concurrent with the reduction in blood concentrations of $\mathrm{Ca}$, concentrations of $\mathrm{Mg}$ in blood increase immediately before and in the first day or 2 after calving (Rodney et al., 2018), followed by a subsequent decline until stabilizing 3 to 4 wk postpartum. The transient hypocalcemia around calving is associated with increased risk of uterine and metabolic disorders (Curtis et al., 1983; Martinez et al., 2012), and peripartum diseases are known to impair productive performance in dairy cows.

Although it is well described that acidogenic diets increase blood concentrations of total (tCa) and ionized $\mathrm{Ca}$ and prevent milk fever, it is less clear what effect these diets have on lactation performance and other diseases. Lean et al. (2014) reviewed the literature on DCAD and milk yield and observed that reducing the DCAD prepartum increased the standardized mean difference in milk yield by 0.63 , which corresponded to approximately $1.15 \mathrm{~kg} / \mathrm{d}$ for the first 65 DIM. Nevertheless, the authors pointed out that the response was heterogeneous and influenced by parity and potentially other aspects, such as concentrations of other minerals in the diet. The effect of acidogenic diets on postpartum DMI and yield of milk components is even less clear, as many of the experiments either did not report productive performance or were not large enough to detect statistical differences.

A decline in concentrations of $\mathrm{Ca}$ in blood around calving can result in typical symptoms of milk fever along with less noticeable subclinical hypocalcemia and increased risk of uterine diseases (Martinez et al., 2012).
Subclinical hypocalcemia is prevalent in dairy cattle in the first $2 \mathrm{~d}$ postpartum (Reinhardt et al., 2011), and it suppresses DMI and induces a period of reduced insulin concentration in dairy cows (Martinez et al., 2014), which might predispose cows to ketosis and displaced abomasum. Therefore, it is anticipated that minimizing the risk of hypocalcemia by manipulating the DCAD of the prepartum diet might reduce not only milk fever, but also a range of other diseases. In any case, the ideal DCAD, interactions with other minerals such as Ca, P, and $\mathrm{Mg}$ in the diet, and responses by cows of distinct parity groups remain mostly unclear.

The hypothesis of the present study was that reducing the DCAD of prepartum diets improves Ca homeostasis, which is beneficial to postpartum health and production performance. A second hypothesis was that using mixed models would allow identification of optimum level of DCAD prepartum and associated concentrations of $\mathrm{Ca}, \mathrm{P}$, and $\mathrm{Mg}$ that benefit productive performance of nulliparous and parous cows. Therefore, the objectives of the study were to use data from the published literature, from experiments in which the mineral composition of prepartum diet was manipulated, to evaluate the effects on production and health of dairy cows.

\section{MATERIALS AND METHODS}

\section{Search of the Published Literature}

A comprehensive search of the literature published in English from 1973 to 2017 was conducted to identify experiments with transition dairy cows that were fed prepartum diets in which the mineral composition was manipulated to alter the DCAD or fed acidogenic diets in which the concentration of $\mathrm{Ca}, \mathrm{P}$, or $\mathrm{Mg}$ was manipulated prepartum. This period encompasses the time when experiments manipulating the mineral composition of prepartum cows applied TMR as the feeding method for delivery of diets. Responses of interest included prepartum DMI, postpartum productive performance, concentrations of minerals and energy metabolites in blood around the peripartum period, and incidence of health problems.

The literature search included 3 search engines, the US National Library of Medicine National Institutes of Health through PubMed (http://www.ncbi.nlm.nih .gov/pubmed), Google Scholar (http://scholar.google .com/), and the ISI Web of Science (http://apps .webofknowledge.com). In addition, searches also were conducted on a database of theses and dissertations (http://www.proquest.com/) and on websites of animal nutrition journals (http://www.publish.csiro.au/). The search was conducted between April 3 and May 5, 
2017, using the terms with a set of 3 keywords in all searches: cow or DCAD or prepartum; cow or anionic salts or prepartum; cow or anionic diets or prepartum; or cow or acidogenic diets or prepartum. For Google Scholar, several thousand hits were collected, and results were sorted in order of relevance and the screening of papers stopped after at least 30 records after the last relevant record was identified. The search aimed to identify publications with experiments that were suitable for further exploration. Whenever a citation in a manuscript identified a reference not listed in the searched database, that publication was then searched. Additional requests were made to individual authors of manuscripts to identify data that might have been collected but not reported in the published paper.

\section{Inclusion and Exclusion Criteria}

The initial criteria for inclusion of experiments was that treatment interventions included manipulation of the DCAD of prepartum diets or that prepartum cows had been fed acidogenic diets and that the concentrations of $\mathrm{Ca}, \mathrm{P}$, or $\mathrm{Mg}$ were manipulated. Experiments had to be either completely randomized designs or randomized block designs with individual feeding of prepartum dietary treatments to cows. Dietary interventions had to be described relative to DCAD and concentrations of $\mathrm{Ca}, \mathrm{P}$, and $\mathrm{Mg}$. The DCAD was calculated as milliequivalents of $\mathrm{K}$ and Na minus milliequivalents of $\mathrm{Cl}$ and $\mathrm{S}$ per kilogram of diet $\mathrm{DM}$, and no restriction was posed relative to the range of DCAD fed prepartum. The manipulations in DCAD and mineral content had to be applied to the diet and not force-fed by oral dosing or through ruminal cannula. Cows had to have free access to the dietary treatments prepartum for ad libitum intake.

Searched literature was screened for duplicates and then suitability for inclusion initially by reading the abstract to assure the experiment was conducted with prepartum dairy cows and that diets were manipulated accordingly. The materials and methods portion of the manuscript was then read to exclude experiments in which treatments were not implemented as previously described or description of diets was not available.

\section{Experiments Included}

Figure 1 depicts a PRISMA diagram (Moher et al., 2009) of the flow of data collection for the meta-analysis. After the initial search and screening, 70 publications including multiple experiments were assessed for eligibility. From those, 28 experiments were excluded because of the following reasons: abstract in English but full article in Chinese (2 experiments); oral or ru- minal dosing of acidogenic products (4 experiments); change-over design (1 experiment); group feeding prepartum (7 experiments); crossover design (1 experiment); dry nonpregnant cow (2 experiments); lack of details of prepartum diets (4 experiments); intake of prepartum diets not reported (2 experiments); the only response reported was urine $\mathrm{pH}$ (2 experiments); pasture feeding (1 experiment); data not reported for individual treatments ( 1 experiment); and treatments applied postpartum (1 experiment). We identified 42 experiments with up to 134 treatment means for use in the meta-analysis. The number of treatment means used in each statistical model depended on availability of data reported in the individual experiments included in the meta-analysis. A list of the experiments included in the meta-analysis is depicted in Table 1 . Table 2 depicts the descriptive statistics of the mineral composition of the diets offered to prepartum cows, and Table 3 depicts the descriptive statistics of production and health responses evaluated and the respective numbers of treatments means included in the analysis of each of the responses evaluated. Throughout the manuscript, parity group is defined based on lactation number prepartum as nulliparous (lactation 0 prepartum and first lactation postpartum) or parous cows (lactation $>0$ prepartum, multiparous postpartum).

\section{Data Extraction}

For responses with continuous data, the experiments had to report individual treatment least squares means and standard error of the mean or means and standard deviation. Frequency data were collected for treatments with the number of affected and not affected individuals for the responses evaluated. Values presented in figures were extracted using an image extraction software (https://automeris.io/WebPlotDigitizer/). Two known data sets used to prepare figures in previously published experiments (Martinez et al., 2018a) were initially used to assure that the software recovered accurate values of least squares means and standard error of the mean from figures.

Data collected for each treatment within experiment included number of cows, parity group prepartum as nulliparous (lactation 0 prepartum, lactation 1 postpartum) or parous cows (lactation $>0$ prepartum, multiparous postpartum), breed of cow (Holstein or other), treatment days prepartum, type of acidogenic product fed (none, acidogenic salts, or commercial acidogenic products), milking frequency, and the macromineral concentration of the prepartum diet (Ca, P, Mg, K, Na, $\mathrm{Cl}$, and S). Five experiments (Bluel, 2006; Chan et al., 2006; Rezac et al., 2014; Wu et al., 2014, 2015) did not separate the results for nulliparous from parous cows; 
parous cows represented $63.5 \%$ of all cows. Because of the predominance of cows that had completed at least 1 lactation before enrollment, these experiments were considered as having parous cows for data analyses.

The DCAD was calculated as $[(\mathrm{mEq}$ of $\mathrm{K}+\mathrm{mEq}$ of $\mathrm{Na})-(\mathrm{mEq}$ of $\mathrm{Cl}+\mathrm{mEq}$ of $\mathrm{S})]$. Responses collected included prepartum DMI, BW, BCS, and urine $\mathrm{pH}$; postpartum DMI, yields of milk and FCM, concentrations and yields of fat and protein in milk, BW, and BCS; incidence of milk fever, retained placenta, metritis, mastitis, and displaced abomasum; concentrations of $\mathrm{Ca}, \mathrm{Mg}$, and $\mathrm{P}$ in blood of cows before calving, on the day of calving, and postpartum; and concentrations of glucose, nonesterified fatty acids (FA), and BHB in blood of cows before and after calving. The range of days prepartum and postpartum when blood samples were collected and analyzed varied with experiments, and most included the last $2 \mathrm{wk}$ of gestation and the first $3 \mathrm{wk}$ postpartum. Responses from different publications were standardized to the same unit using the metric system, percent, and, for concentrations of analytes in blood, as millimoles per liter or millimolar.

Data were transferred to Excel spreadsheets (version 2016, Microsoft Corp., Redmond, WA) and reviewed by 2 people to assure information collected was accurately transcribed from the manuscripts into the spreadsheets before statistical analyses.

\section{Statistical Analysis}

Data were analyzed by the MIXED and GLIMMIX procedures of SAS (SAS ver. 9.4, SAS/STAT, SAS

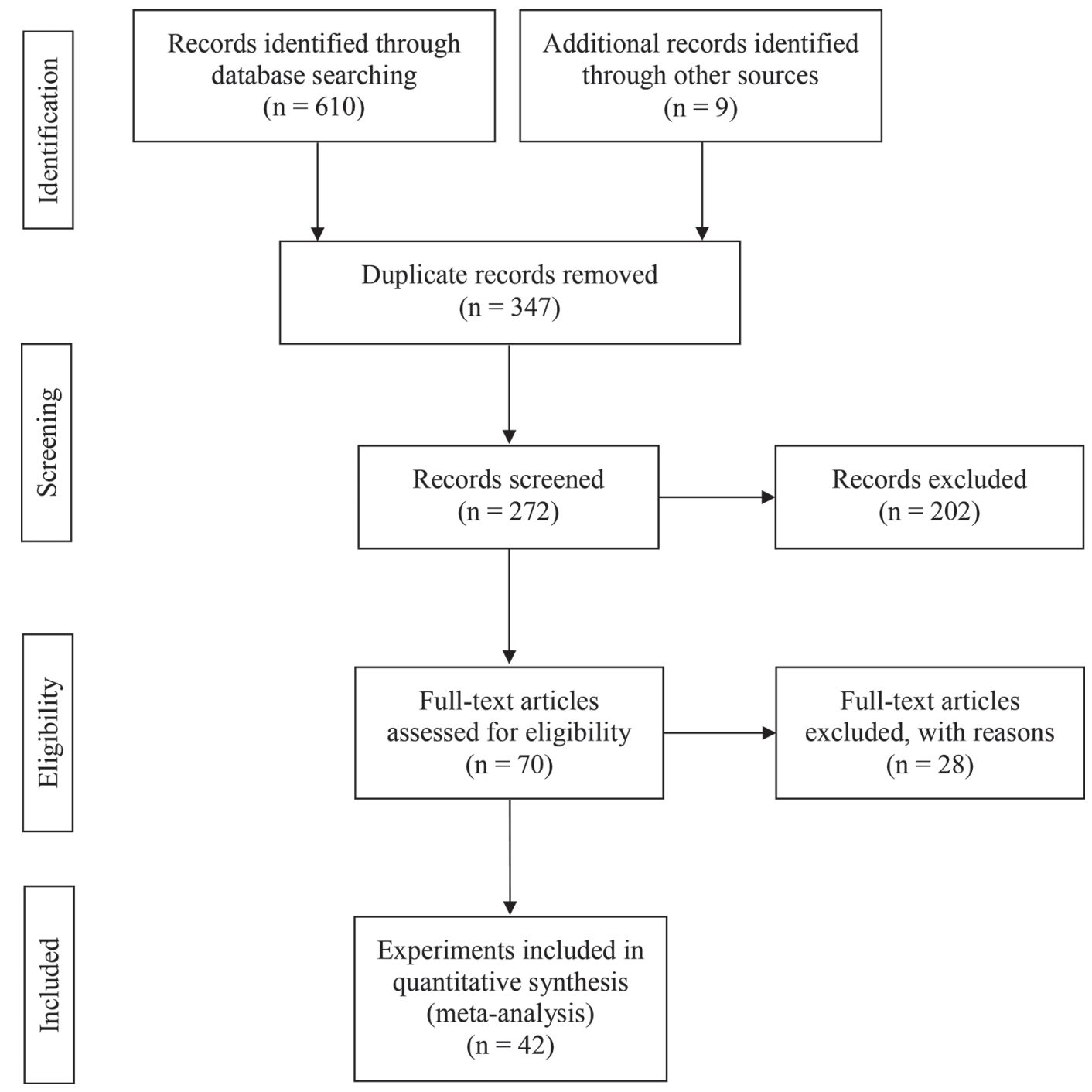

Figure 1. The PRISMA flow diagram (Moher et al., 2009) of the systematic review from initial search and screening to final selection of publications to be included in the meta-analysis. The 42 selected articles for inclusion in the meta-analysis contained each a single experiment; therefore, we used 42 experiments. 
Institute Inc., Cary, NC). Predictors considered for statistical models were first inspected for multicollinearity for every response analyzed using collinearity analysis (Collin) in the REG prcedure of SAS and inspecting condition index, tolerance, and variance inflation fac- tor. In all models, the predictors considered included level of DCAD (mEq/kg), parity prepartum (nulliparous or parous), breed of cow (Holstein or other), days on prepartum treatment, and dietary concentrations (\%) of $\mathrm{Ca}, \mathrm{P}$, and $\mathrm{Mg}$. For all responses evaluated, we

Table 1. List of references used in the meta-analysis

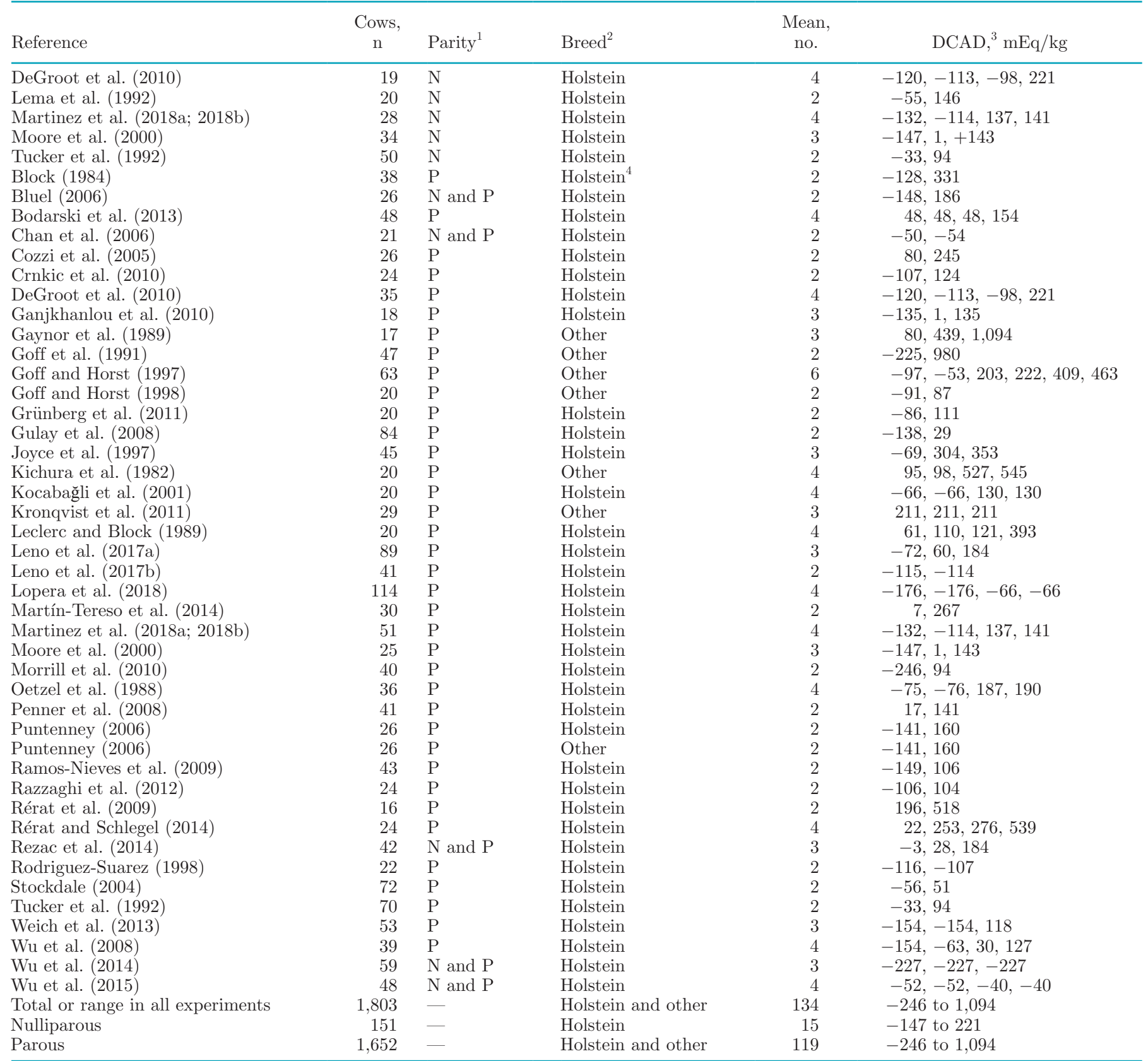

${ }^{1} \mathrm{~N}=$ nulliparous prepartum and primiparous postpartum; $\mathrm{P}=$ parous prepartum and multiparous postpartum; $\mathrm{N}$ and $\mathrm{P}=$ experiment with nulliparous and parous cows prepartum and data not reported according to parity. For those experiments, cows were considered to be parous. ${ }^{2}$ Other $=$ includes Jersey and Swedish Red.

${ }^{3}$ Dietary cation-anion difference calculated as $\mathrm{DCAD}=[(\mathrm{mEq}$ of $\mathrm{Na}+\mathrm{mEq}$ of $\mathrm{K})-(\mathrm{mEq}$ of $\mathrm{S}+\mathrm{mEq} \mathrm{Cl})]$. Each value represents the $\mathrm{DCAD}$ of the diet offered to the cows of a given treatment within experiment.

${ }^{4}$ The manuscript included 12 Holstein and 8 Ayrshire cows used in 2 experiments in consecutive years, but breed was considered as Holstein because results were not reported separately for each breed. 
Table 2. Descriptive statistics of mineral composition of diets offered to prepartum cows and intake of minerals according to parity group

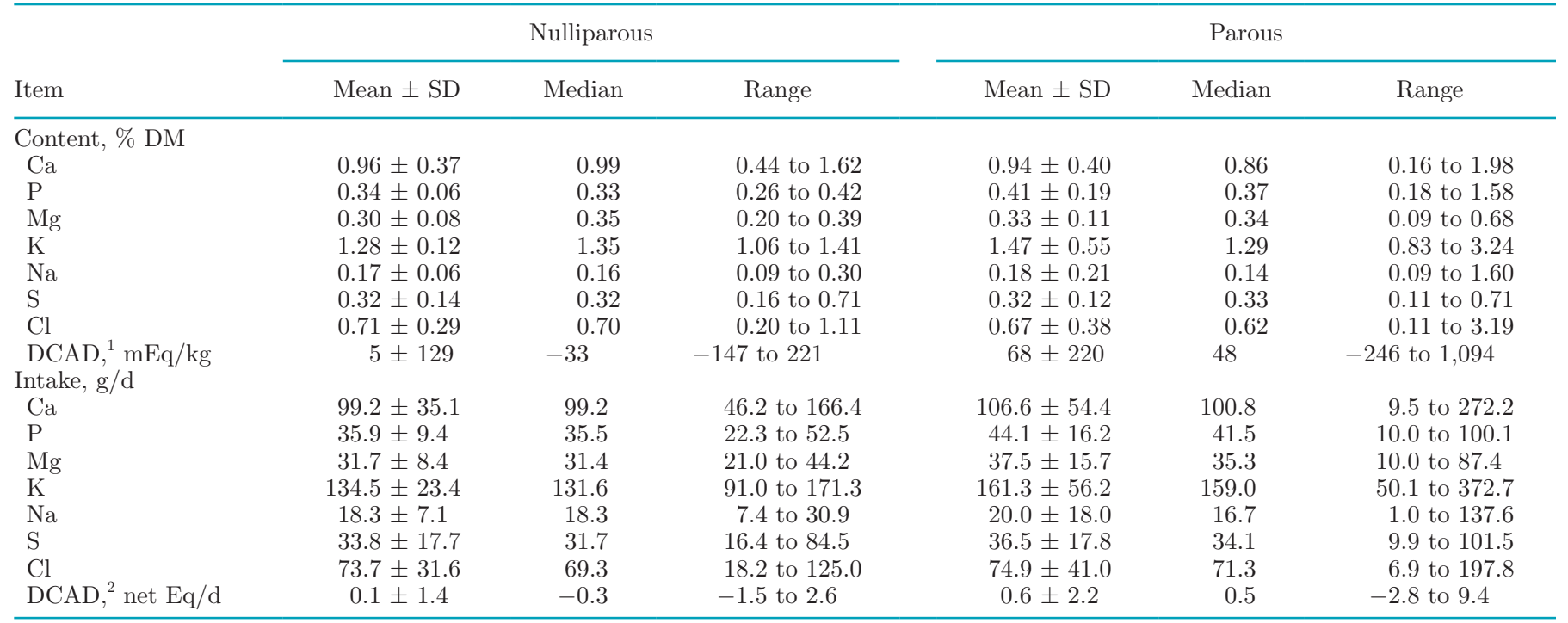

${ }^{1}$ Dietary cation-anion difference calculated as DCAD $=[(\mathrm{mEq}$ of $\mathrm{Na}+\mathrm{mEq}$ of $\mathrm{K})-(\mathrm{mEq}$ of $\mathrm{S}+\mathrm{mEq}$ of $\mathrm{Cl})]$.

${ }^{2}$ Intake of net equivalents (Eq) considered the DCAD of the diet offered and the DMI prepartum; for example, cows fed a diet with $-50 \mathrm{mEq} /$ $\mathrm{kg}$ and DMI of $11 \mathrm{~kg} / \mathrm{d}$ would result in a net Eq intake of $-0.55 \mathrm{Eq} / \mathrm{d}$, indicating that this cow consumed 0.55 more Eq of anions than cations.

found no indication of multicollinearity based on condition index always less than 28 and variance inflation factors smaller than 2.0 .

Continuous variables were analyzed by the MIXED procedure of SAS (SAS/STAT) with estimations carried out by the method of restricted estimated maximum likelihood. All mixed models included the random effect of experiment and responses were weighted using the WEIGHT statement in SAS (SAS/STAT) based on the precision of the experiment with the inverse of variance squared $\left(1 / \mathrm{SEM}^{2}\right)$ that was centered for each response analyzed as suggested by Wang and Bushman (1999). Statistical models were built following the general matrix notation of a mixed model:

Table 3. Descriptive statistics of production and health responses evaluated in the study according to parity group

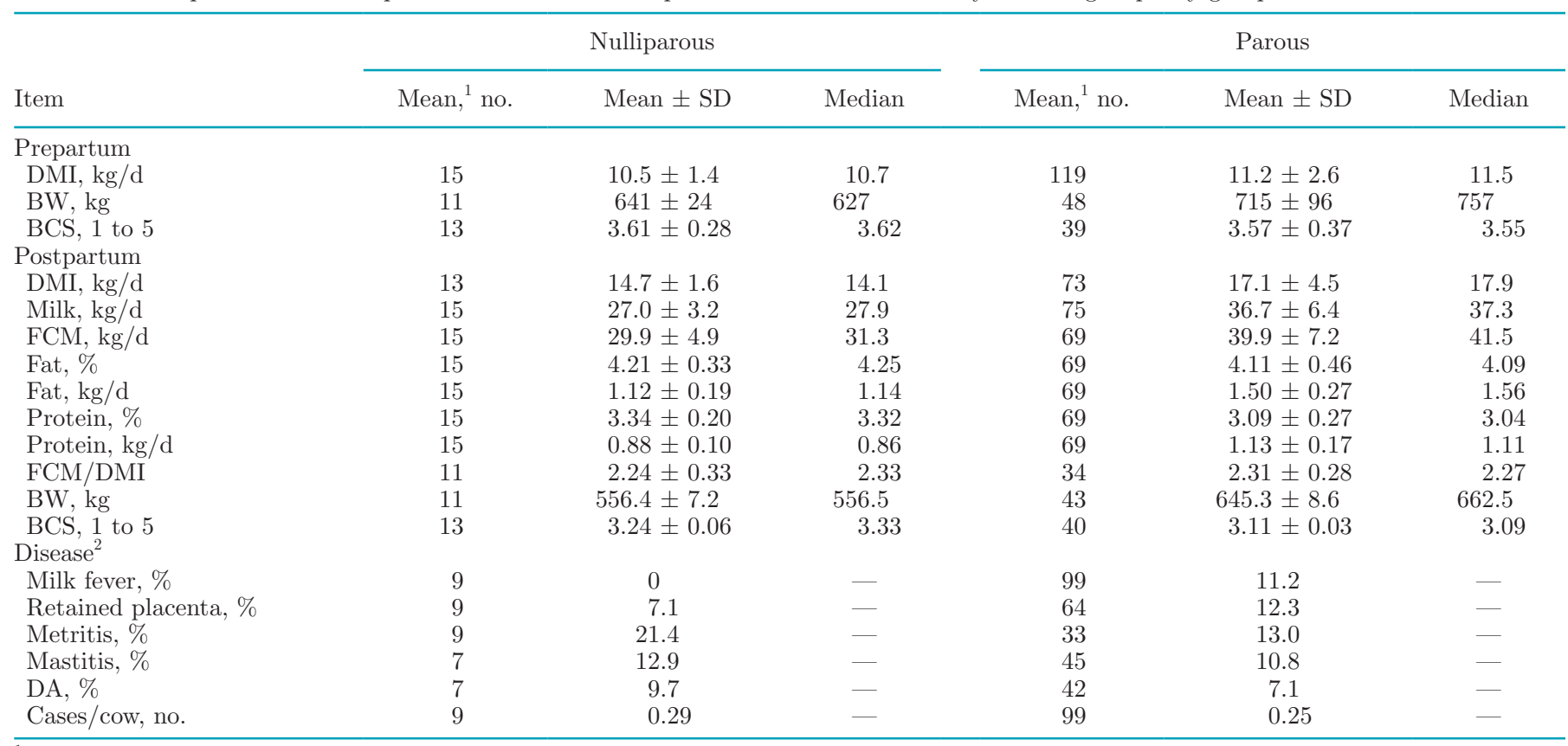

${ }^{1}$ Number of treatment means that contributed data for the analyses.

${ }^{2} \mathrm{DA}=$ displaced abomasum. 


$$
y=\mathbf{X} \boldsymbol{\beta}+\mathbf{Z}_{\boldsymbol{\gamma}}+\varepsilon,
$$

where $y$ is the response analyzed, $\mathbf{X}$ is the design matrix corresponding to the fixed effects and the associated vector $\boldsymbol{\beta}$ of the regression coefficients, $\mathbf{Z}$ is the matrix for the random effects with the vector $\gamma$ of their associated coefficients, and $\varepsilon$ is the random error assumed to be normally distributed with mean 0 and a homogeneous variance. Univariable analyses were performed to determine if each response was associated with DCAD, parity, breed, days on prepartum treatment, or dietary concentrations of Ca, P, or Mg. Subsequently, predictors that resulted in univariable models with $P<0.20$ were included in multivariable models. The full multivariable model built if all univarible predictors had $P<0.20$ included the fixed effects of DCAD, parity, breed, days on treatment, $\mathrm{Ca}, \mathrm{P}, \mathrm{Mg}$, the interactions of DCAD and parity, DCAD and breed, DCAD and Ca, $\mathrm{DCAD}$ and $\mathrm{P}$, and $\mathrm{DCAD}$ and $\mathrm{Mg}$, and the quadratic effects of DCAD, Ca, P, and Mg. A backward elimination procedure was applied at each step with removal of model parameters if $P>0.10$, with the highest order term removed from the model sequentially according to the largest $P$-value. At each step, model fit was assessed using the corrected Akaike's information criterion and variance inflation was evaluated, and in all models the parameters retained resulted in variance inflation factors less than 2.20. Each model was rerun multiple times until all parameters resulted in $P \leq 0.10$ or model fit improved. Final model selection was based on significance, model fit based on smallest corrected Akaike's information criterion, and parsimony. Distribution of residuals and homogeneity of variance was evaluated visually for final models. The effects of DCAD, parity prepartum, and interaction between DCAD and parity prepartum were forced in the final models even if $P$ $>0.10$. Once a final model was selected, the random slope of DCAD was evaluated using an unstructured variance-covariance structure. Only the random slope of DCAD was evaluated because the models did not converge when more than one independent variable was analyzed with random slopes. If the random slope of DCAD was not significant $(P>0.10)$, it was removed from the final model.

Incidence of diseases was analyzed by logistic regression with the GLIMMIX procedure of SAS (SAS/ STAT) fitting binomial distribution. Model building was as previously described and model fitting was assessed based on -2 Log-likelihood values. Dispersion of the data was assessed by the ratio of the generalized chi-squared statistic and its degrees of freedom. In almost all final models, the generalized $\chi^{2} / \mathrm{df}$ was between 0.95 and 1.10, indicating that the variability in the data was properly modeled and that only minor residual under- or over-dispersion was present in any of the final models built. In a few models, dispersion problems were observed, and a multiplicative dispersion parameter estimated from Pearson's statistic was added to the models. Predicted probabilities from the mixed models were computed as least squares means \pm standard error of the mean on the scale of the data with the ILINK function, concurrent with the respective adjusted odds ratios (OR) and 95\% confidence intervals (CI).

Two additional statistical models were built, one to understand how dietary minerals influenced responses in diets with positive or negative DCAD and another to understand the association between urine $\mathrm{pH}$ and risk of milk fever. For the case of dietary minerals, if the final statistical models for blood tCa on the day of calving, risk of milk fever, and risk of retained placenta included significant effects of dietary $\mathrm{Ca}$, $\mathrm{P}$, or $\mathrm{Mg}$, then additional models were built including the category of DCAD (diet with positive or negative DCAD) and the interaction between category of DCAD and the mineral. To understand the relationship between urine $\mathrm{pH}$ and risk of milk fever, the effect of DCAD was removed from the statistical model and urine $\mathrm{pH}$ as linear and quadratic covariates were included. Whenever the interaction between DCAD and parity was significant $(P \leq 0.05)$, the response was analyzed for nulliparous and parous cows separately to determine if the interaction was caused because contrasting effects of DCAD according to parity prepartum.

Figures were generated with predicted responses to DCAD according to parity based on random (BLUP) and fixed effects (best linear unbiased estimates) from mixed models. Fitted values with best linear unbiased estimates for altering the DCAD were computed for nulliparous and parous Holstein cows after implementing the final statistical models and assuming that cows were fed prepartum diets for $21 \mathrm{~d}$ containing $0.60 \% \mathrm{Ca}$, $0.30 \% \mathrm{P}$, and $0.35 \% \mathrm{Mg}$, but varying DCAD between 200 or $-100 \mathrm{mEq} / \mathrm{kg}$. This was done to exemplify the expected responses to altering the DCAD from an alkalogenic to an acidogenic diet. Statistical significance was considered at $P \leq 0.05$, and tendency was considered at $0.05<P \leq 0.10$.

\section{RESULTS}

The number of experiments reporting data for nulliparous was only 5 , a total of 151 cows, with a range of DCAD fed from -147 to $222 \mathrm{mEq} / \mathrm{kg}$ of DM (Table 1 ). On the other hand, 41 experiments reported data for parous cows, resulting in 1,652 cows fed diets with a wider range of DCAD, from -246 to $1,094 \mathrm{mEq} / \mathrm{kg}$ of DM (Table 1). Because only few experiments were avail- 
able with nulliparous cows, the diversity of diet mineral composition was more limited than that observed for parous cows (Table 2). Duration of prepartum feeding of diets reported in the experiments averaged $( \pm \mathrm{SD})$ $21.9 \pm 1.8$ and $25.6 \pm 1.0 \mathrm{~d}$ for nulliparous and parous cows, respectively. Descriptive statistics of number of treatment means reported, production performance, and incidence of diseases according to parity group is presented in Table 3 .

\section{DMI, BW, and BCS Prepartum}

A total of 115 treatment means from 36 experiments reported DMI prepartum. A quadratic effect $(P=$ 0.008) of DCAD was observed for DMI prepartum in nulliparous and parous cows (Table 4) after controlling for parity $(P<0.001)$, breed $(P<0.001)$ and the linear $(P=0.12)$ and quadratic $(P=0.06)$ effects of dietary Ca. Reducing the prepartum DCAD from 200 to $-100 \mathrm{mEq} / \mathrm{kg}$ predicted a 0.7 and $0.4 \mathrm{~kg} / \mathrm{d}$ reduction in DMI in Holstein nulliparous and parous cows, respectively (Table 5). Concentrations of $\mathrm{P}$ and $\mathrm{Mg}$ in prepartum diets did not influence DMI prepartum, but intake tended $(P=0.06)$ to increase in a quadratic fashion with dietary $\mathrm{Ca}$ concentration up to $0.80 \%$, when intake plateaued. We further analyzed data on prepartum DMI by removing DCAD from the model and including type of acidogenic product fed as none, salts, or commercial products to determine if the depression was induced by use of a particular source of strong ions. Inclusion of salts or commercial product reduced $(P<0.01)$ DMI prepartum irrespective of the source of strong ions fed (none $=9.0 \pm 0.4$ vs. salts $=$ $8.5 \pm 0.4$ vs. commercial products $=8.4 \pm 0.4 \mathrm{~kg} / \mathrm{d}$ ).

Body weight and BCS prepartum were not influenced by DCAD or by the interaction between DCAD and parity group. Concentrations of $\mathrm{Ca}, \mathrm{P}$, and $\mathrm{Mg}$ in prepartum diets did not affect BW or BCS prepartum. No interactions between DCAD and $\mathrm{Ca}, \mathrm{P}$, or $\mathrm{Mg}$ were observed for BW and BCS prepartum.

\section{Postpartum Performance}

Intake postpartum was reported in 26 experiments with 86 treatment means (Table 3). A reduction in prepartum DCAD resulted in a tendency $(P=0.08)$ for increased postpartum DMI in nulliparous and parous cows (Table 4, Figure 2E), with an approximately $1 \mathrm{~kg} / \mathrm{d}$ increase in DMI by reducing the prepartum DCAD from 200 to $-100 \mathrm{mEq} / \mathrm{kg}$ (Table 5). Dietary concentrations of $\mathrm{Ca}, \mathrm{P}$, and $\mathrm{Mg}$ prepartum did not influence DMI postpartum.
An interaction $(P=0.03)$ between DCAD and parity group was observed for milk yield because reducing the DCAD fed to parous cows increased $(P<0.001)$ milk yield, but in nulliparous cows reducing the prepartum DCAD did not affect $(P=0.20)$ milk yield (Table 4 ; Figure 2A). Concentrations of $\mathrm{Ca}, \mathrm{P}$, and $\mathrm{Mg}$ in prepartum diets did not influence milk yield. Yield of FCM followed a similar pattern to that of milk yield, with an interaction $(P=0.002)$ between DCAD and parity group (Figure $2 \mathrm{~B})$. Reducing the DCAD increased $(P$ $=0.003) \mathrm{FCM}$ yield in parous cows, but it tended $(P=$ 0.06 ) to reduce FCM yield in nulliparous cows (Table 4). Concentrations of $\mathrm{Ca}, \mathrm{P}$, and $\mathrm{Mg}$ in prepartum diets did not influence yield of FCM. Efficiency of FCM yield per kilogram of DMI did not differ with DCAD (Figure $2 \mathrm{~F}$ and Table 5).

Concentration and yield of fat in milk were affected by the interaction between DCAD and parity group. A reduction in DCAD decreased $(P=0.007)$ milk fat content in nulliparous cows, but it had no effect on parous cows (Table 4). Dietary Ca and P affected milk fat content. Dietary Ca had a quadratic effect $(P=0.001)$ on milk fat and reached a plateau when dietary $\mathrm{Ca}$ was between 0.8 and $1.2 \%$ of the diet DM. Increasing dietary $\mathrm{P}$ reduced $(P=0.02)$ milk fat content. Interactions between DCAD and parity were detected for yields of fat and protein (Figure $2 \mathrm{C}$ and $2 \mathrm{D}$ ). Reducing the DCAD decreased $(P=0.04)$ yield of milk fat in nulliparous cows but increased $(P=0.02)$ yield in parous cows. On the other hand, reducing the DCAD tended $(P=0.07)$ to reduce protein yield in nulliparous cows but increased $(P=0.04)$ yield of protein in parous cows (Table 4). The estimated increments in yields of milk fat and protein in parous cows from reducing the DCAD from 200 to $-100 \mathrm{mEq} / \mathrm{kg}$ were 74 and 24 $\mathrm{g} / \mathrm{d}$, respectively (Table 5). Dietary concentrations of $\mathrm{Ca}, \mathrm{P}$, or $\mathrm{Mg}$ prepartum did not affect yields of milk components. Prepartum DCAD did not influence BW or BCS postpartum; reducing the DCAD from 200 to $-100 \mathrm{mEq} / \mathrm{kg}$ resulted in minor differences in those responses in both nulliparous and parous cows (Table 5).

\section{Urine $\mathrm{pH}$ and Concentrations of Minerals in Blood}

A quadratic effect $(P<0.001)$ of DCAD was observed for urine $\mathrm{pH}$ (Figure 3A). Urine $\mathrm{pH}$ increased from 5.4 at a DCAD of $-246 \mathrm{mEq} / \mathrm{kg}$ to a plateau of 8.4 when DCAD was $300 \mathrm{mEq} / \mathrm{kg}$. Concentration of dietary $\mathrm{Mg}$ was positively associated with urine $\mathrm{pH}(P$ $=0.03$; coefficient 1.502). In addition, concentration of dietary Ca had a quadratic $(P=0.02)$ association with urine $\mathrm{pH}$ and the linear and quadratic coefficients were 1.239 and -0.504 , respectively. 
SANTOS ET AL.

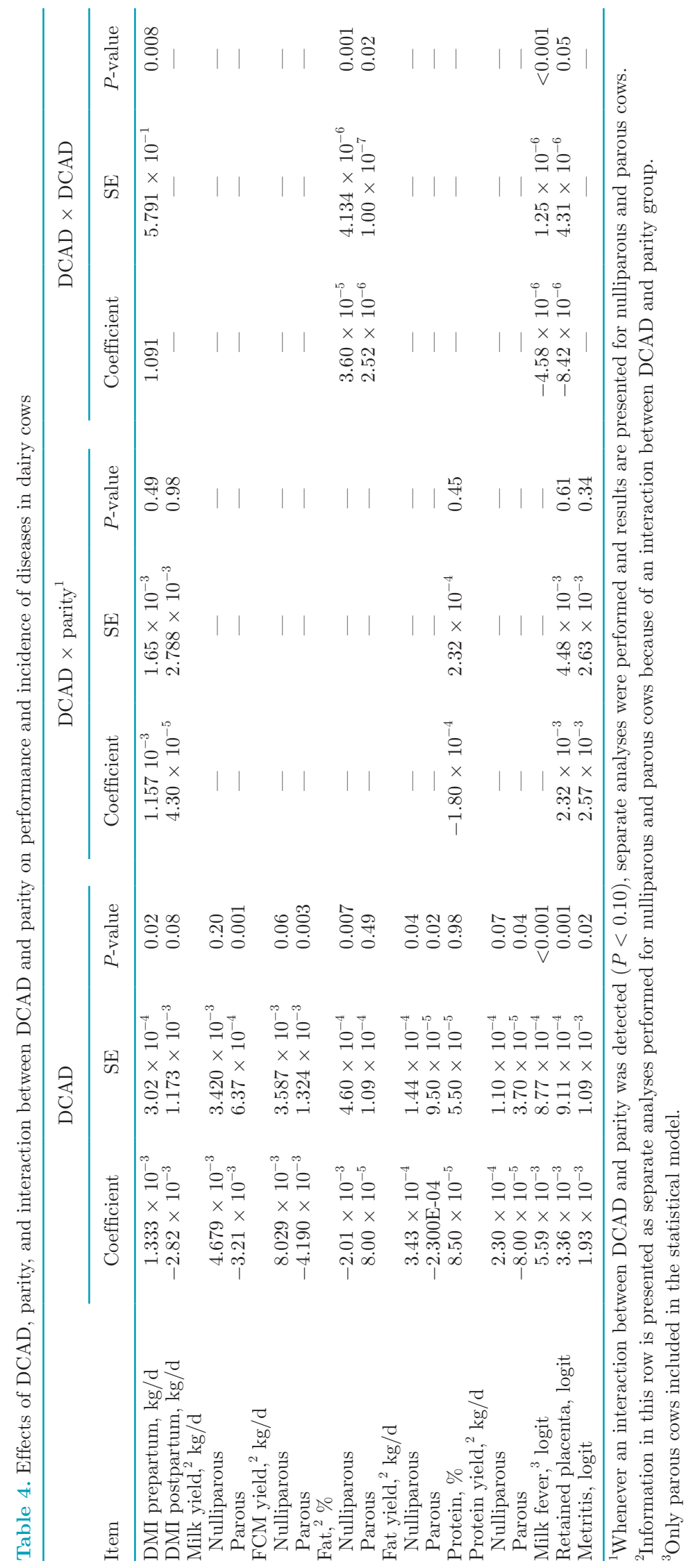


Table 5. Effect of reducing the DCAD from +200 to $-100 \mathrm{mEq} / \mathrm{kg}$ on estimated intake and lactation performance in Holstein cows according to parity group $(\mathrm{LSM} \pm \mathrm{SEM})$

\begin{tabular}{|c|c|c|c|c|c|c|c|}
\hline Item & $\begin{array}{l}\text { Means } \\
(\text { Exp. })^{1}\end{array}$ & \multicolumn{2}{|c|}{ Nulliparous } & \multicolumn{2}{|c|}{ Parous } & \multicolumn{2}{|r|}{$P$-value ${ }^{2}$} \\
\hline Prepartum & $115(36)$ & $10.3 \pm 0.5$ & $9.6 \pm 0.5$ & $12.4 \pm 0.4$ & $12.0 \pm 0.4$ & 0.02 & 0.49 \\
\hline Postpartum & $86(26)$ & $12.9 \pm 0.9$ & $13.7 \pm 0.9$ & $17.7 \pm 0.7$ & $18.7 \pm 0.7$ & 0.08 & 0.98 \\
\hline Milk yield, kg/d & $90(28)$ & $25.9 \pm 1.3^{\mathrm{c}}$ & $24.5 \pm 1.3^{\mathrm{c}}$ & $36.2 \pm 1.1^{\mathrm{b}}$ & $37.9 \pm 1.1^{\mathrm{a}}$ & 0.74 & 0.03 \\
\hline FCM yield, $\mathrm{kg} / \mathrm{d}$ & $84(25)$ & $26.6 \pm 1.9^{c}$ & $24.5 \pm 1.9^{\mathrm{d}}$ & $38.8 \pm 1.8^{\mathrm{b}}$ & $39.9 \pm 1.8^{\mathrm{a}}$ & 0.90 & 0.002 \\
\hline Yield, $\mathrm{kg} / \mathrm{d}$ & $84(25)$ & $0.995 \pm 0.073^{\mathrm{c}}$ & $\begin{array}{c}3.80 \pm 0.10 \\
0.888 \pm 0.073^{\mathrm{d}}\end{array}$ & $1.438 \pm 0.066^{\mathrm{b}}$ & $\begin{array}{r}4.13 \pm 0.0 r^{\mathrm{a}} \\
1.512 \pm 0.066^{\mathrm{a}}\end{array}$ & $\begin{array}{l}0.10 \\
0.60\end{array}$ & $\begin{array}{r}<0.001 \\
0.006\end{array}$ \\
\hline \multicolumn{8}{|l|}{ Protein } \\
\hline$\%$ & $84(25)$ & $3.22 \pm 0.08$ & $3.25 \pm 0.08$ & $3.25 \pm 0.07$ & $3.23 \pm 0.07$ & 0.98 & 0.45 \\
\hline Yield, kg/d & $84(25)$ & $0.755 \pm 0.053^{\mathrm{c}}$ & $0.695 \pm 0.053^{\mathrm{c}}$ & $1.115 \pm 0.047^{\mathrm{b}}$ & $1.139 \pm 0.047^{\mathrm{a}}$ & 0.44 & 0.07 \\
\hline \multicolumn{8}{|l|}{$\mathrm{BW}, \mathrm{kg}$} \\
\hline Prepartum & $59(17)$ & $610.4 \pm 16.5$ & $604.1 \pm 16.5$ & $750.1 \pm 16.2$ & $743.2 \pm 16.2$ & 0.17 & 0.92 \\
\hline
\end{tabular}

${ }^{\mathrm{a}-\mathrm{d}}$ Within a row, values with different superscripts differ $(P<0.05)$.

${ }^{1}$ Number of treatment means and number of experiments (Exp.) that contributed with data for the analyses.

${ }^{2} \mathrm{DCAD}=$ linear effect of altering the DCAD; DCAD $\times$ parity $=$ interaction between the linear effect of altering the DCAD and parity $($ nulliparous or parous).

Prepartum DCAD did not affect the concentration of tCa in blood prepartum (Figure 4A). In fact, reducing the DCAD from 200 to $-100 \mathrm{mEq} / \mathrm{kg}$ resulted in no significant change in concentrations of tCa in nulliparous or parous cows (Table 6). On the day of calving, concentrations of tCa in blood increased $(P<0.001)$ with decreasing the DCAD in both nulliparous and parous cows (Figure 4B). Dietary Ca or P did not influence blood tCa on the day of calving (Figures 5A and $5 \mathrm{~B})$; however, increasing the concentration of dietary $\mathrm{Mg}$ reduced $(P=0.02)$ blood tCa (Figure $5 \mathrm{C})$. Similar to the day of calving, reducing the DCAD increased $(P$ $<0.001$ ) blood tCa concentrations postpartum (Figure $4 \mathrm{C})$. Dietary Ca and P did not affect blood tCa concentrations postpartum, but dietary $\mathrm{Mg}$ had a quadratic effect $(P=0.005)$ on blood tCa, which decreased as dietary $\mathrm{Mg}$ increased. The DCAD of prepartum diets did not affect blood concentrations of $\mathrm{Mg}$ prepartum, at calving, or postpartum (Figures 4D, 4E, 4F). Dietary concentrations of $\mathrm{Ca}, \mathrm{Mg}$, or $\mathrm{P}$ did not influence blood concentrations of $\mathrm{Mg}$ prepartum, at calving, or postpartum. Blood concentrations of $\mathrm{P}$ were not influenced by DCAD of prepartum diets (Figures 4G, 4H, 4I). Increasing dietary $\mathrm{P}$ prepartum increased (coefficient $\left.4.306 \times 10^{-1} ; P=0.01\right)$ blood $\mathrm{P}$ concentrations prepartum and tended to increase (coefficient $4.193 \times 10^{-1}$; $P=0.08$ ) on the day of calving, but not postpartum. Concentrations of $\mathrm{Ca}$ or $\mathrm{Mg}$ in the diet prepartum did not affect blood concentrations of $\mathrm{P}$.

\section{Concentrations of Metabolites in Blood}

Dietary cation-anion difference affected $(P=0.02)$ the concentration of glucose in blood prepartum, and concentrations decreased with a reduction in DCAD in nulliparous and parous cows (Table 7). Concentrations of glucose in blood postpartum were not affected by prepartum DCAD. Nulliparous cows had greater $(P<$ $0.001)$ blood glucose than parous cows pre- and postpartum, but no interactions between DCAD and parity were observed for glucose concentrations in blood. Prepartum DCAD did not affect blood concentrations of FA prepartum; however, an interaction $(P=0.02)$ between DCAD and parity group was detected postpartum for concentrations of FA in blood. In nulliparous cows, prepartum DCAD did not affect postpartum concentrations of FA in blood; however, reducing the DCAD prepartum increased blood FA postpartum. (Table 7). A reduction in prepartum DCAD tended $(P=0.07)$ to decrease the concentrations of BHB in blood prepartum and decreased $(P=0.02)$ postpartum (Table 7).

\section{Incidence of Diseases}

Milk fever affected only parous cows and parity group was excluded from the statistical model. Level of DCAD had a quadratic effect $(P<0.001)$ on the risk of milk fever (Figure 6A); the predicted incidence reduced 
from 11.7 to $2.8 \%$ by reducing the DCAD from 200 to $-100 \mathrm{mEq} / \mathrm{kg}$ (Table 8 ). When urine $\mathrm{pH}$ replaced DCAD in the statistical model for risk of milk fever, a linear relationship $(P<0.001)$ was observed and the risk of milk fever decreased with a reduction in urine
$\mathrm{pH}$ (Figure 3B). Prepartum concentrations of dietary P or $\mathrm{Mg}$ did not influence the risk of milk fever (Figures $5 \mathrm{E}$ and $5 \mathrm{~F})$; however, increasing dietary $\mathrm{Ca}$ content tended $(P=0.06)$ to increase the incidence of milk fever (Figure 5D). No interaction $(P=0.18)$ between
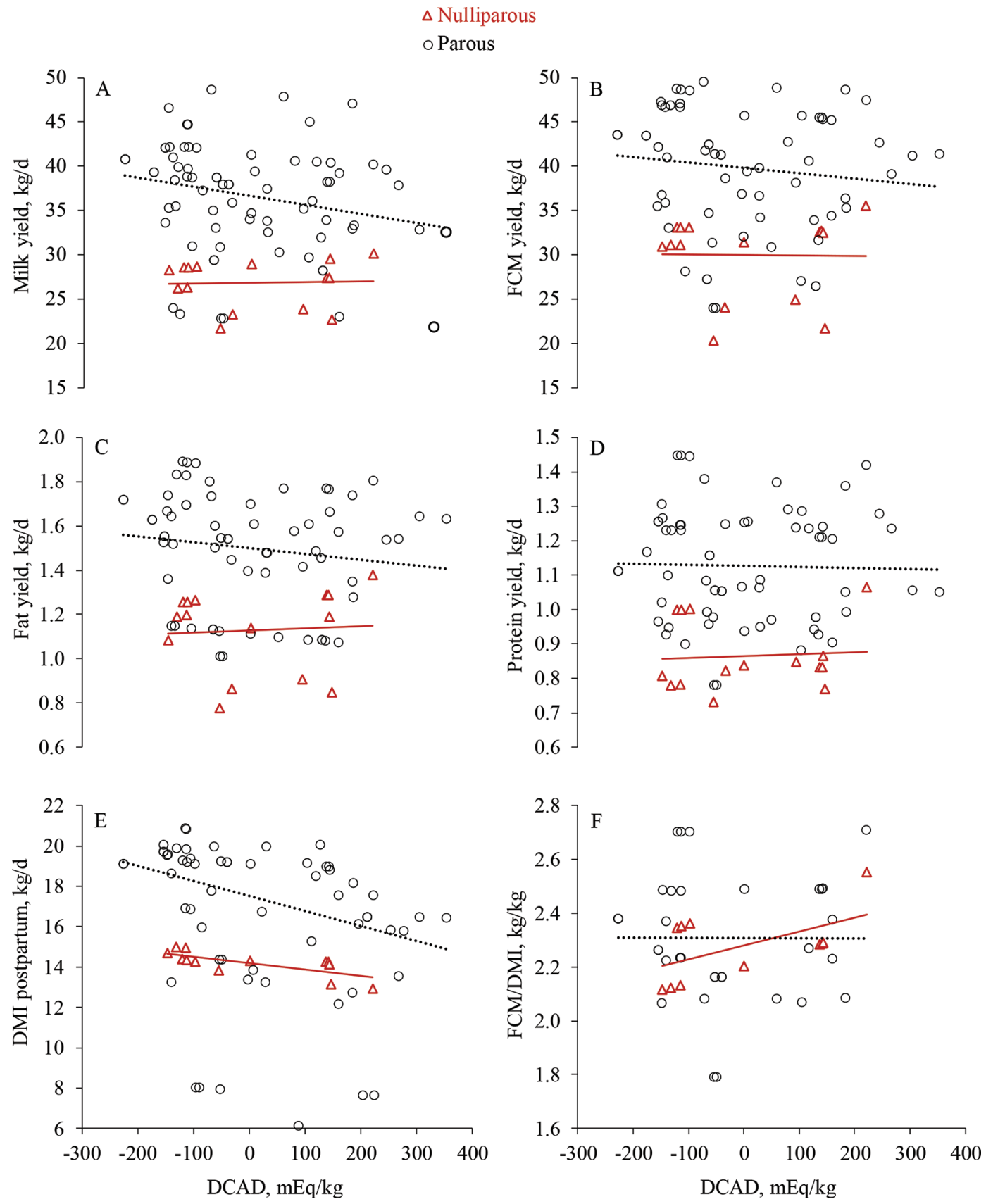

Figure 2. Postpartum performance in nulliparous (triangle) and parous cows (circle) according to prepartum DCAD fed. Milk yield (A); effect of DCAD $(P=0.74)$, parity $(P<0.001)$, and interaction between DCAD and parity $(P=0.03)$. Fat-corrected milk yield $(\mathrm{B})$; effect of DCAD $(P=0.90)$, parity $(P<0.001)$, and interaction between DCAD and parity $(P=0.002)$. Fat yield $(\mathrm{C})$; effect of DCAD $(P=0.60)$, parity $(P<0.001)$, and interaction between DCAD and parity $(P=0.006)$. Protein yield $(\mathrm{D})$; effect of DCAD $(P=0.44)$, parity $(P<0.001)$, and interaction between DCAD and parity $(P=0.07)$. Dry matter intake $(\mathrm{E})$; effect of DCAD $(P=0.08)$, parity $(P<0.001)$, and interaction between DCAD and parity $(P=0.98)$. Fat-corrected milk yield over DMI $(\mathrm{F})$; effect of DCAD $(P=0.22)$, parity $(P=0.002)$, and interaction between DCAD and parity $(P=0.25)$. 
DCAD and dietary Ca was observed for risk of milk fever. To further understand the data, we analyzed the risk of milk fever with the final statistical model but also included the effects of category of DCAD, positive or negative, and of the interaction between category of DCAD and dietary Ca content. In the latter case, an interaction $(P=0.03)$ between category of DCAD and dietary $\mathrm{Ca}$ content was observed because of the effect of $\mathrm{Ca}$ increasing the risk of milk fever was more pronounced in cows fed acidogenic than alkalogenic diets (Figure 5D).

Incidence of retained placenta decreased $(P=0.05)$ in a quadratic fashion with a reduction in DCAD (Figure $6 \mathrm{~B}$ ), and no interaction between DCAD and parity group was observed (Table 4). Concentrations of dietary $\mathrm{Ca}, \mathrm{P}$, or $\mathrm{Mg}$ did not affect the risk of retained placenta (Figures $5 \mathrm{G}, 5 \mathrm{H}$, and $5 \mathrm{I}$ ). A reduction in DCAD from 200 to $-100 \mathrm{mEq} / \mathrm{kg}$ resulted in a marked reduction in predicted incidence of retained placenta in dairy cows (Table 8). Incidence of metritis decreased linearly $(P$ $=0.02$ ) with a reduction in DCAD of prepartum diets (Figure 6C), and no interaction between DCAD and parity group was observed (Table 4). Dietary concentrations of $\mathrm{Ca}, \mathrm{Mg}$, or $\mathrm{P}$ did not affect the risk of metritis. The incidence of mastitis and displaced abomasum were not influenced by the DCAD of prepartum diets (Figure 6D and 6E), and no interaction between DCAD and parity group were observed for those 2 diseases. Number of disease events per cow declined $(P<0.001)$ in a quadratic fashion with a reduction in DCAD of prepartum diets (Figure 6F), and the decline was ob- served in nulliparous and parous cows. Concentrations of $\mathrm{Ca}, \mathrm{Mg}$, or $\mathrm{P}$ in prepartum diets did not influence the number of disease events per cow. Reducing the DCAD from 200 to $-100 \mathrm{mEq} / \mathrm{kg}$ decreased by half the number of disease events per cow (Table 8).

\section{DISCUSSION}

Overwhelming evidence from controlled experiments support feeding acidogenic diets prepartum to reduce the risk of clinical and subclinical hypocalcemia in dairy cows (Ender et al., 1971; Dishington, 1975; Block, 1984; Martinez et al., 2018b); however, less certainty exists about the effects of acidogenic diets on lactation performance and incidence of diseases other than hypocalcemia. The current study demonstrated that reducing the DCAD of prepartum diets not only increased concentrations of tCa in blood and reduced the risk of milk fever, but it also reduced the risk of retained placenta, metritis, and the number of health events per cow in both nulliparous and parous cows. Reducing the DCAD decreased DMI prepartum but increased DMI postpartum and improved yields of milk and FCM in parous cows, but not in nulliparous cows.

A common response from feeding acidogenic diets is a reduction in DMI prepartum. Charbonneau et al. (2006) demonstrated a linear positive relationship between DCAD and prepartum intake; that is, reducing the DCAD of prepartum diets caused a reduction in DMI prepartum. Nevertheless, feeding acidogenic diets has been shown to improve intake postpartum in nullip-

$\triangle$ Nulliparous

○ Parous
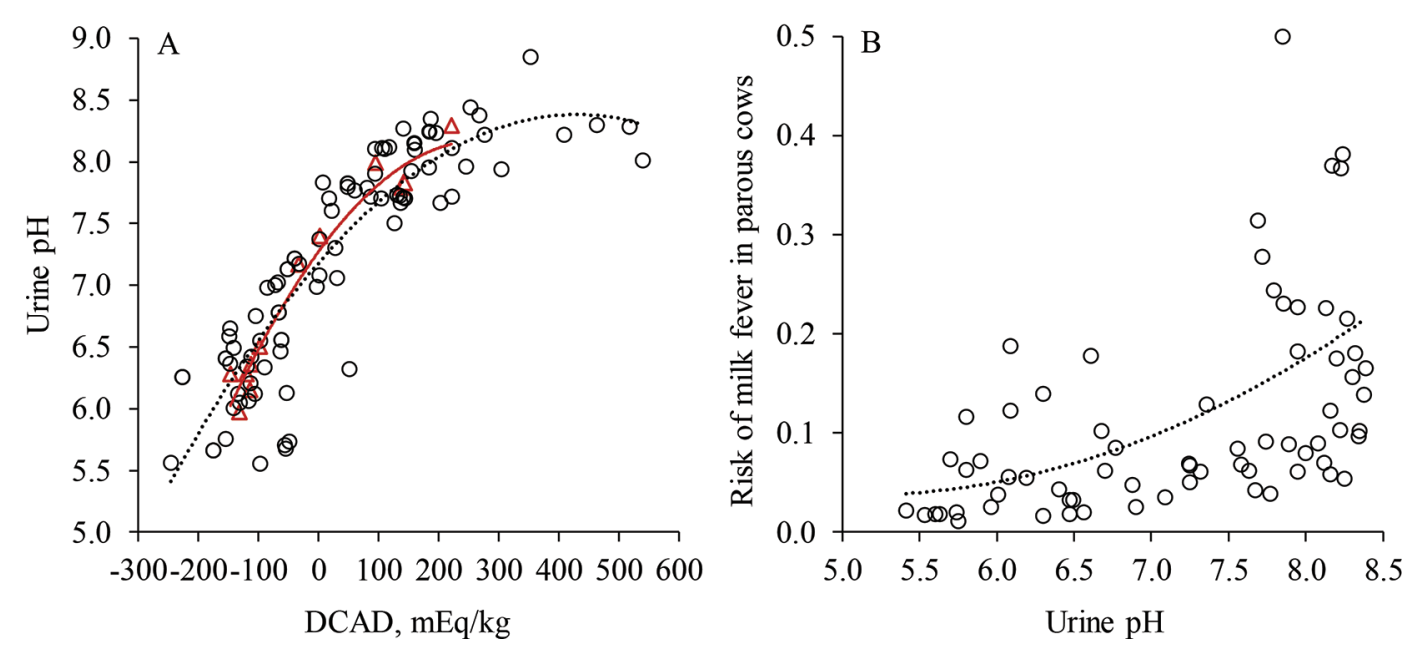

Figure 3. Urine $\mathrm{pH}$ in nulliparous (triangle) or parous cows (circle) according to DCAD (A) and risk of milk fever in parous cows according to urine $\mathrm{pH}(\mathrm{B})$. For urine $\mathrm{pH}$, linear effect of $\mathrm{DCAD}(P<0.001)$, quadratic effect of DCAD $(P<0.001)$, parity $(P=0.86)$, and interaction between DCAD and parity $(P=0.43)$. For risk of milk fever, linear effect of DCAD $(P<0.001)$. 
arous (Lema et al., 1992) and parous cows (Joyce et al., 1997), presumably by improving Ca metabolism and minimizing the risk of hypocalcemia, which is known to depress intake (Martinez et al., 2014), or by reducing retained placenta and metritis, which also reduce DMI. The current study showed that reducing the DCAD caused a reduction in DMI prepartum, but the same reduction in DCAD improved intake postpartum. The decline in intake prepartum seems to be induced by the metabolic acidosis and not by use of a particular source of strong ions supplemented to the diet (Vagnoni and Oetzel, 1998; Zimpel et al., 2018). Zimpel et al. (2018) recently showed that feeding a diet with negative DCAD induced a compensated metabolic acidosis and depressed DMI, but the same diet with acidogenic product supplemented with salts containing strong cations to result in a positive DCAD prevented the depression in intake. When we discriminated between acidogenic salts and commercial acidogenic products, both caused a similar depression in DMI prepartum.
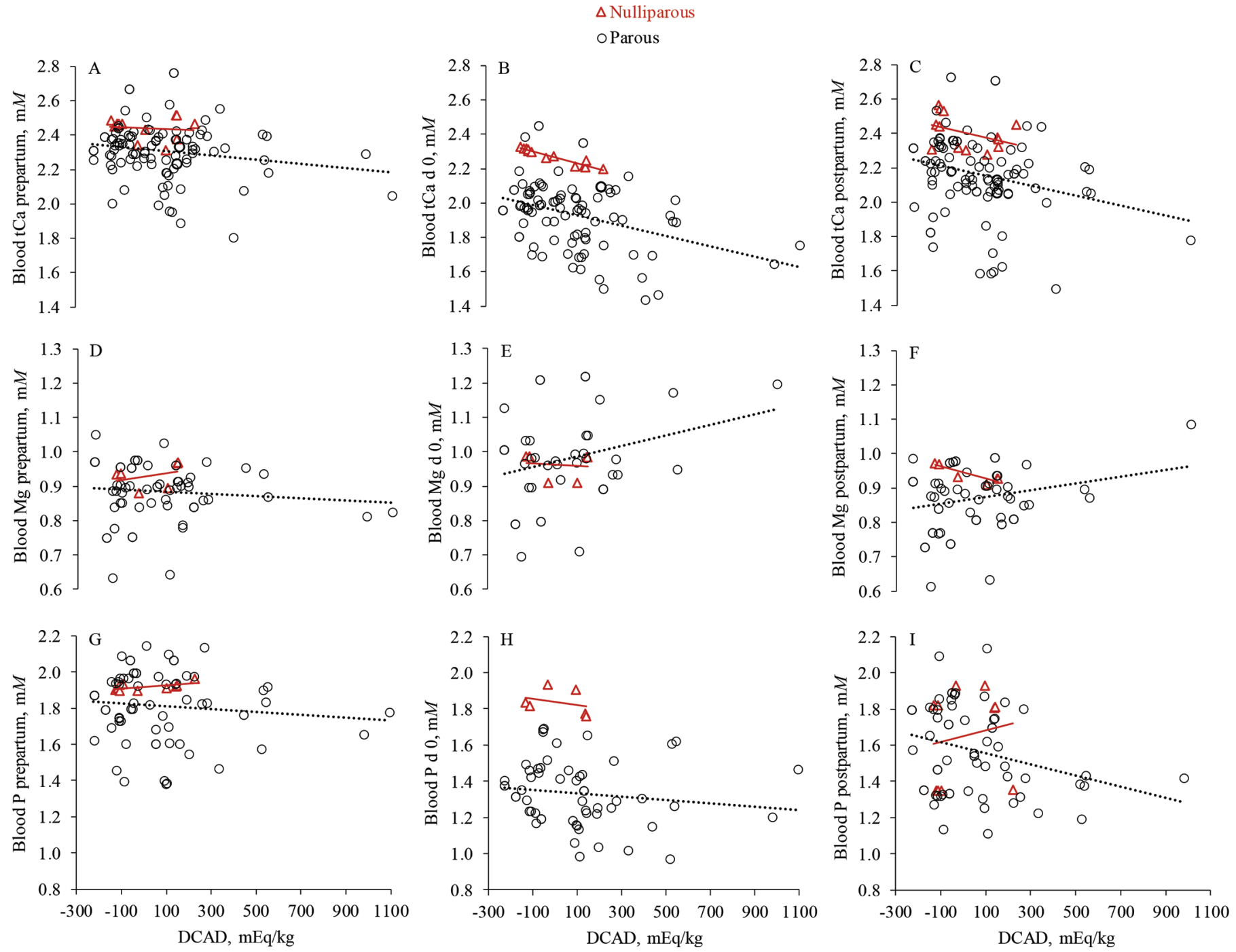

Figure 4. Blood mineral concentrations in nulliparous (triangle) and parous cows (circle) according to prepartum DCAD fed. Blood total $\mathrm{Ca}(\mathrm{tCa})$ concentrations prepartum $(\mathrm{A})$; effect of DCAD $(P=0.77)$, parity $(P<0.001)$, interaction between DCAD and parity $(P=0.58)$. Blood tCa concentrations on the day of calving (B); effect of DCAD $(P<0.001)$, parity $(P<0.001)$, interaction between DCAD and parity $(P$ $=0.15)$. Blood tCa concentrations postpartum $(\mathrm{C})$; effect of DCAD $(P<0.001)$, parity $(P<0.001)$, interaction between DCAD and parity $(P$ $=0.31$. Blood $\mathrm{Mg}$ concentrations prepartum $(\mathrm{D})$; effect of DCAD $(P=0.80)$, parity $(P=0.27)$, interaction between DCAD and parity $(P=$ 0.76). Blood $\mathrm{Mg}$ concentrations on the day of calving (E); effect of DCAD $(P=0.15)$, parity $(P=0.13)$, and interaction between DCAD and parity $(P=0.22)$. Blood $\mathrm{Mg}$ concentrations postpartum $(\mathrm{F})$; effect of DCAD $(P=0.65)$, parity $(P=0.29)$, interaction between DCAD and parity $(P=0.19)$. Blood $\mathrm{P}$ concentrations prepartum $(\mathrm{G})$; effect of DCAD $(P=0.82)$, parity $(P=0.64)$, interaction between DCAD and parity $(P=0.71)$. Blood $\mathrm{P}$ concentrations on the day of calving $(\mathrm{H})$; effect of DCAD $(P=0.02)$, parity $(P<0.001)$, and interaction between DCAD and parity $(P=0.37)$. Blood $\mathrm{P}$ concentrations postpartum $(\mathrm{I})$; effect of DCAD $(P=0.62)$, parity $(P=0.20)$, interaction between DCAD and parity $(P=0.53)$. 
Table 6. Effect of reducing the DCAD from +200 to $-100 \mathrm{mEq} / \mathrm{kg}$ on estimated urine $\mathrm{pH}$ and blood concentrations of minerals in Holstein cows according to parity group (LSM $\pm \mathrm{SEM})$

\begin{tabular}{|c|c|c|c|c|c|c|c|}
\hline \multirow[b]{2}{*}{ Item } & \multirow{2}{*}{$\begin{array}{l}\text { Means } \\
(\text { Exp. })^{1}\end{array}$} & \multicolumn{2}{|c|}{ Nulliparous } & \multicolumn{2}{|c|}{ Parous } & \multicolumn{2}{|r|}{$P$-value ${ }^{2}$} \\
\hline & & +200 & -100 & +200 & -100 & DCAD & $\mathrm{DCAD} \times$ parity \\
\hline Prepartum & $113(35)$ & $2.465 \pm 0.048$ & $2.460 \pm 0.048$ & $2.320 \pm 0.039$ & $2.344 \pm 0.039$ & 0.77 & 0.58 \\
\hline Day of calving & $107(33)$ & $2.295 \pm 0.065$ & $2.394 \pm 0.065$ & $1.860 \pm 0.046$ & $2.044 \pm 0.046$ & $<0.001$ & 0.15 \\
\hline Postpartum & $115(36)$ & $2.363 \pm 0.056$ & $2.440 \pm 0.056$ & $2.104 \pm 0.050$ & $2.224 \pm 0.050$ & $<0.001$ & 0.31 \\
\hline Day of calving & $47(15)$ & $0.920 \pm 0.052$ & $0.923 \pm 0.052$ & $0.987 \pm 0.039$ & $0.970 \pm 0.039$ & 0.82 & 0.77 \\
\hline Postpartum & $66(21)$ & $0.901 \pm 0.033$ & $0.929 \pm 0.033$ & $0.916 \pm 0.022$ & $0.884 \pm 0.022$ & 0.65 & 0.19 \\
\hline \multicolumn{8}{|l|}{ Blood $\mathrm{P}, \mathrm{m} M$} \\
\hline Prepartum & $77(24)$ & $1.755 \pm 0.073$ & $1.745 \pm 0.073$ & $1.757 \pm 0.045$ & $1.779 \pm 0.045$ & 0.92 & 0.79 \\
\hline Day of calving & $51(17)$ & $1.695 \pm 0.106$ & $1.737 \pm 0.106$ & $1.118 \pm 0.055$ & $1.370 \pm 0.055$ & 0.15 & 0.37 \\
\hline Postpartum & $74(23)$ & $1.737 \pm 0.080$ & $1.732 \pm 0.080$ & $1.665 \pm 0.072$ & $1.703 \pm 0.072$ & 0.62 & 0.53 \\
\hline
\end{tabular}

${ }^{1}$ Number of treatment means and number of experiments (Exp.) that contributed with data for the analyses.

${ }^{2} \mathrm{DCAD}=$ linear effect of altering the DCAD; DCAD $\times$ parity $=$ interaction between the linear effect of altering the DCAD and parity $($ nulliparous or parous).

The differences in intake prepartum likely explain the reduction in concentrations of blood glucose with a reduction in DCAD.

Production of milk and FCM increased with a reduction in DCAD, but the improvement was observed only in parous cows. Heterogeneity in response to manipulations in DCAD prepartum have been reported by others (Lean et al., 2014), and productive responses of nulliparous to acidogenic diets do not seem to be the same as that observed for parous cows. Parous cows are more prone to disturbances of Ca metabolism with the onset of lactation (Lean et al., 2006), and hypocalcemica is known to depress appetite (Martinez et al., 2014), which might affect lactation performance. Although the current study showed that a reduction in prepartum DCAD increased blood $\mathrm{Ca}$ on the day of calving and postpartum in nulliparous and parous cows, the latter had smaller concentrations of Ca than the former. In addition, milk fever only affected cows in the parous group, thus reinforcing that they are more likely to benefit from acidogenic diets preventing a disturbance in Ca metabolism. Most experiments that used nulliparous cows were unable to show statistical differences in productive performance when fed acidogenic diets, even when postpartum DMI tended to increase by reducing the DCAD prepartum (Lema et al., 1992). Perhaps nulliparous cows partitioned nutrients from increased DMI toward growth and development rather than milk. It is also possible that nulliparous cows respond differently than parous cows to manipulations of acid-base balance prepartum. It is possible that the changes in blood $\mathrm{Ca}$ and the smaller prevalence of subclinical hypocalcemia in nulliparous than in parous cows is insufficient to compromise lactation perfor- mance, precluding potential benefits from acidogenic diets prepartum. Furthermore, the current study had a more robust database for parous than nulliparous cows. The number of experiments and treatment means were larger for parous than nulliparous, thereby increasing the power to detect differences and the precision of the estimates. Only 5 experiments reported data from nulliparous cows, and the range of DCAD fed in those experiments was narrower than that fed to parous cows. Perhaps the limitation in the data might have precluded detection of a clearer response of nulliparous cows to manipulations of prepartum DCAD. The stimulation of yields of milk and milk components in parous cows fed diets with smaller DCAD likely explains the increase in blood FA concentrations as the DCAD of prepartum diets decreased.

Reducing the DCAD of prepartum diets resulted in a clear improvement in concentrations of tCa in blood on the day of calving and the days following calving. Acidogenic diets favor Ca metabolism in part by enhancing the action of parathyroid hormone in dairy cows (Goff et al., 2014). This increment in blood tCa resulted in a smaller risk of milk fever in parous cows, approaching an incidence of 2 to $3 \%$ when diets contained a DCAD of $-100 \mathrm{mEq} / \mathrm{kg}$. The benefits of feeding acidogenic diets prepartum in preventing milk fever have been extensively reported in the literature (Charbonneau et al., 2006; Lean et al., 2006) and corroborates current findings. Nevertheless, an important finding of this meta-analysis is that the benefits of acidogenic diets are not limited to milk fever. Reducing the DCAD of prepartum diets reduced the risk of retained placenta and metritis, supporting the concept that hypocalcemia is a gateway disease and that minimizing low blood $\mathrm{Ca}$ 

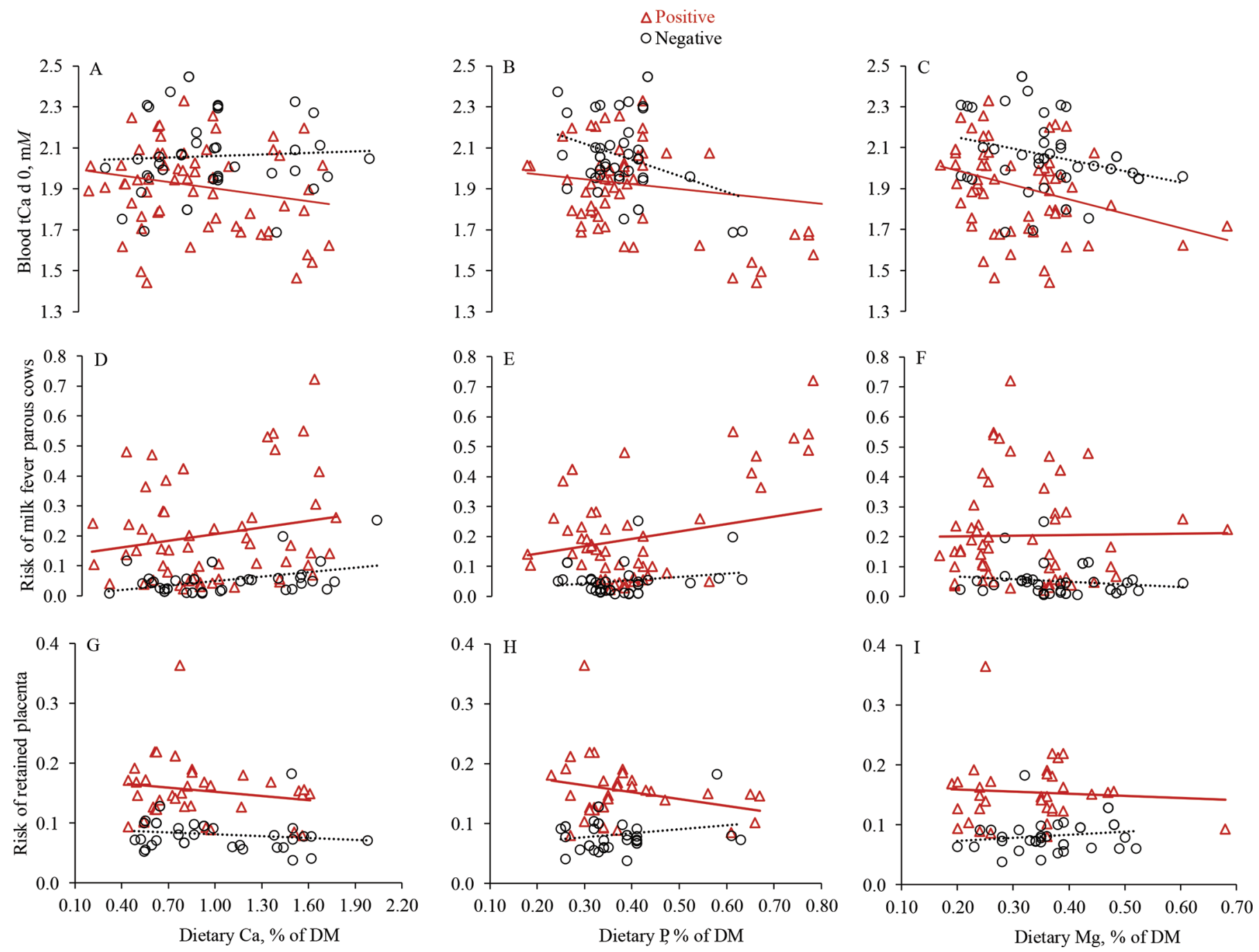

Figure 5. Concentrations of total $\mathrm{Ca}(\mathrm{tCa}, \mathrm{m} M$ ) in blood on the day of calving (A to $\mathrm{C}$ ), risk of milk fever in parous cows (proportion affected; D to F), and risk of retained placenta (proportion affected; G to I) according to dietary concentrations of Ca, $\mathrm{P}$, or Mg and diets with positive (DCAD $\geq 0 \mathrm{mEq} / \mathrm{kg}$; triangle) or negative DCAD (DCAD $<0 \mathrm{mEq} / \mathrm{kg}$; circle). Blood concentrations of tCa, effects of dietary Ca (A; $P$ $=0.47)$, dietary $\mathrm{P}(\mathrm{B} ; P=0.38)$, and dietary $\mathrm{Mg}(\mathrm{C} ; P=0.02)$. Risk of milk fever in parous cows, effects of dietary Ca $(\mathrm{D} ; P=0.06)$, dietary $\mathrm{P}(\mathrm{E} ; P=0.84)$, and dietary $\mathrm{Mg}(\mathrm{F} ; P=0.80)$. Risk of retained placenta, effects of dietary $\mathrm{Ca}(\mathrm{G} ; P=0.72)$, dietary $\mathrm{P}(\mathrm{H} ; P=0.69)$, and dietary $\mathrm{Mg}(\mathrm{I} ; P=0.57)$.

at calving and in the following days can reduce the risk of uterine diseases in dairy cows (Martinez et al., 2012). For instance, in parous cows, based on the current findings, reducing the DCAD from 200 to $-100 \mathrm{mEq} / \mathrm{kg}$ resulted in a relative risk of 0.53 and 0.61 for retained placenta and metritis, respectively. Such reductions likely explain the increments in postpartum DMI and productive performance observed in parous cows when fed acidogenic diets prepartum. Milk fever and peripartum diseases of inflammatory nature such as metritis are known to impair intake and performance of cows.

Concentrations of $\mathrm{Ca}$ in blood are critical for proper smooth muscle contractility and for activation of innate and adaptive immune responses. Hypocalcemia has been shown to reduce motility of the reproductive tract (Robalo Silva and Noakes, 1984; Al-Eknah and Noakes, 1989), which likely predisposes accumulation of tissues and lochia that promote bacterial growth in the uterus. In addition, hypocalcemia blunts activation of lymphocytes (Kimura et al., 2006) and depresses function of blood PMNL (Martinez et al., 2014). Innate immune response is critical for shedding of the placenta and protection of the uterus to eliminate infection after calving (Bondurant, 1999). Therefore, prevention of clinical and subclinical hypocalcemia by feeding acidogenic diets prepartum likely explains the reduced incidence of retained placenta and metritis in dairy cows. 
As the DCAD decreased, so did urine $\mathrm{pH}$, and this relationship was quadratic. Nevertheless, when nulliparous and parous cows were fed diets with negative $\mathrm{DCAD}$, the relationship between DCAD and urine $\mathrm{pH}$ was linear at least up to the lower limit of DCAD in the database of $-246 \mathrm{mEq} / \mathrm{kg}$. Charbonneau et al. (2006) demonstrated a very similar relationship irrespective of what equation the authors used to calculate the DCAD. Based on the current findings, to achieve a mean urine $\mathrm{pH}$ between 5.5 and 6.5 , both nulliparous and parous cows have to be fed diets with DCAD between -100 and $-200 \mathrm{mEq} / \mathrm{kg}$. A linear association between urine $\mathrm{pH}$ and risk of milk fever was also established, and incidence was predicted to be less than $5 \%$ when urine $\mathrm{pH}$ was below 6.5. Obviously, the underlying link between urine $\mathrm{pH}$ and milk fever was the DCAD, and cows fed diets with DCAD smaller than $-100 \mathrm{mEq} / \mathrm{kg}$ had urine $\mathrm{pH}$ smaller than 6.5 and a marked decrease in the risk of milk fever.

Despite the benefits to reducing the risk of milk fever, retained placenta, and metritis, the incidence of mastitis and displaced abomasum did not differ when altering the DCAD in prepartum diets. An important aspect in our study is that in several experiments authors reported that some cows that developed disease were removed from the statistical analyses, although they had been exposed to treatments before calving. Although we collected data from 42 experiments and up to 134 treatment means, several of those experiments did not collect or report health data. Milk fever and retained placenta were the most commonly reported diseases, with 99 and 73 treatment means, respectively; however, metritis, mastitis, and displaced abomasum were reported in less than half of the treatment means collected. Some peripartum diseases are more likely to affect cows that are fed alkalogenic rather than acidogenic diets prepartum (Ender et al., 1971; Dishington,
1975; Block, 1984). Milk fever increases the risk of several other diseases in early lactation (Curtis et al., 1983; Martinez et al., 2012). When authors remove cows from analyses because of disease events around calving, there is a risk for potential bias in data reporting that would affect the estimates of the effects of treatments with manipulations of the DCAD reported herein. It is possible that under-reporting of health data and removal of cows from analyses might lead to underestimation of the true benefit of acidogenic diets on health and performance of dairy cows.

In addition to the effects of DCAD, one of the goals of this meta-analysis was to identify potential relationships between concentrations of $\mathrm{Ca}, \mathrm{Mg}$, or $\mathrm{P}$ in the diet with production and health responses in dairy cows. The diets fed had reasonable ranges of concentrations of those minerals, particularly for parous cows, although the number of diets and ranges were limited for nulliparous cows. Nevertheless, only a few responses were influenced by dietary concentrations of $\mathrm{Ca}, \mathrm{Mg}$, or $\mathrm{P}$. Increasing the concentration of $\mathrm{Ca}$ in the diet prepartum tended to increase the risk of milk fever, and the response was linear within the range of dietary $\mathrm{Ca}$ fed in the experiments in the database. The adjusted odds ratio (95\% CI) was 1.79 (0.95 to 3.36), suggesting that each percentage unit increment in dietary content of $\mathrm{Ca}$ (e.g., from 0.6 to $1.6 \%$ ) is expected to increase the odds of having milk fever by almost 1.8 fold. Interestingly, when we included category of DCAD, positive or negative, in the final statistical model for milk fever, an interaction between level of dietary $\mathrm{Ca}$ and DCAD category was observed. Increasing dietary $\mathrm{Ca}$ tended to increase the risk of milk fever, but the effect was greater in cows fed acidogenic rather than alkalogenic diets. For instance, for a cow fed an alkalogenic diet of $+200 \mathrm{mEq} / \mathrm{kg}$, increasing dietary Ca from 0.6 to $1.6 \%$ increased the risk of milk fever from 14.4 to $17.7 \%$, a

Table 7. Effect of reducing the DCAD from +200 to $-100 \mathrm{mEq} / \mathrm{kg}$ on estimated blood concentrations of metabolites in Holstein cows according to parity group (LSM \pm SEM)

\begin{tabular}{|c|c|c|c|c|c|c|c|}
\hline Item & $\begin{array}{l}\text { Means } \\
(\text { Exp. })^{1}\end{array}$ & \multicolumn{2}{|c|}{ Nulliparous } & \multicolumn{2}{|c|}{ Parous } & \multicolumn{2}{|r|}{$P$-value ${ }^{2}$} \\
\hline \multicolumn{8}{|c|}{ Blood glucose, $\mathrm{m} M$} \\
\hline Postpartum & $43(22)$ & $3.765 \pm 0.106$ & $3.753 \pm 0.106$ & $3.373 \pm 0.081$ & $3.379 \pm 0.081$ & 0.97 & 0.91 \\
\hline \multicolumn{8}{|c|}{ Blood fatty acids, $\mathrm{m} M$} \\
\hline Prepartum & $55(15)$ & $0.249 \pm 0.040$ & $0.224 \pm 0.040$ & $0.255 \pm 0.036$ & $0.261 \pm 0.036$ & 0.51 & 0.29 \\
\hline Prepartum & $40(10)$ & $0.501 \pm 0.061$ & $0.468 \pm 0.061$ & $0.572 \pm 0.057$ & $0.531 \pm 0.057$ & 0.07 & 0.83 \\
\hline Postpartum & $48(13)$ & $0.595 \pm 0.099$ & $0.441 \pm 0.099$ & $0.892 \pm 0.086$ & $0.843 \pm 0.086$ & 0.02 & 0.21 \\
\hline
\end{tabular}

${ }^{1}$ Number of treatment means and number of experiments (Exp.) that contributed with data for the analyses.

${ }^{2} \mathrm{DCAD}=$ linear effect of altering the DCAD; DCAD $\times$ parity $=$ interaction between the linear effect of altering the DCAD and parity $($ nulliparous or parous). 
relative increment of 1.23 fold. On the other hand, if cows were fed a diet with $-100 \mathrm{mEq} / \mathrm{kg}$, increasing dietary $\mathrm{Ca}$ from 0.6 to $1.6 \%$ increased the risk of milk fever from 2.0 to $7.7 \%$, a relative increase in the risk of 3.85 fold. Dietary Ca influenced urine $\mathrm{pH}$, and as $\mathrm{Ca}$ increased so did urine $\mathrm{pH}$. Increasing dietary $\mathrm{Ca}$ intake and consequent gastrointestinal absorption exerts alkalogenic effects because it is a strong cation,

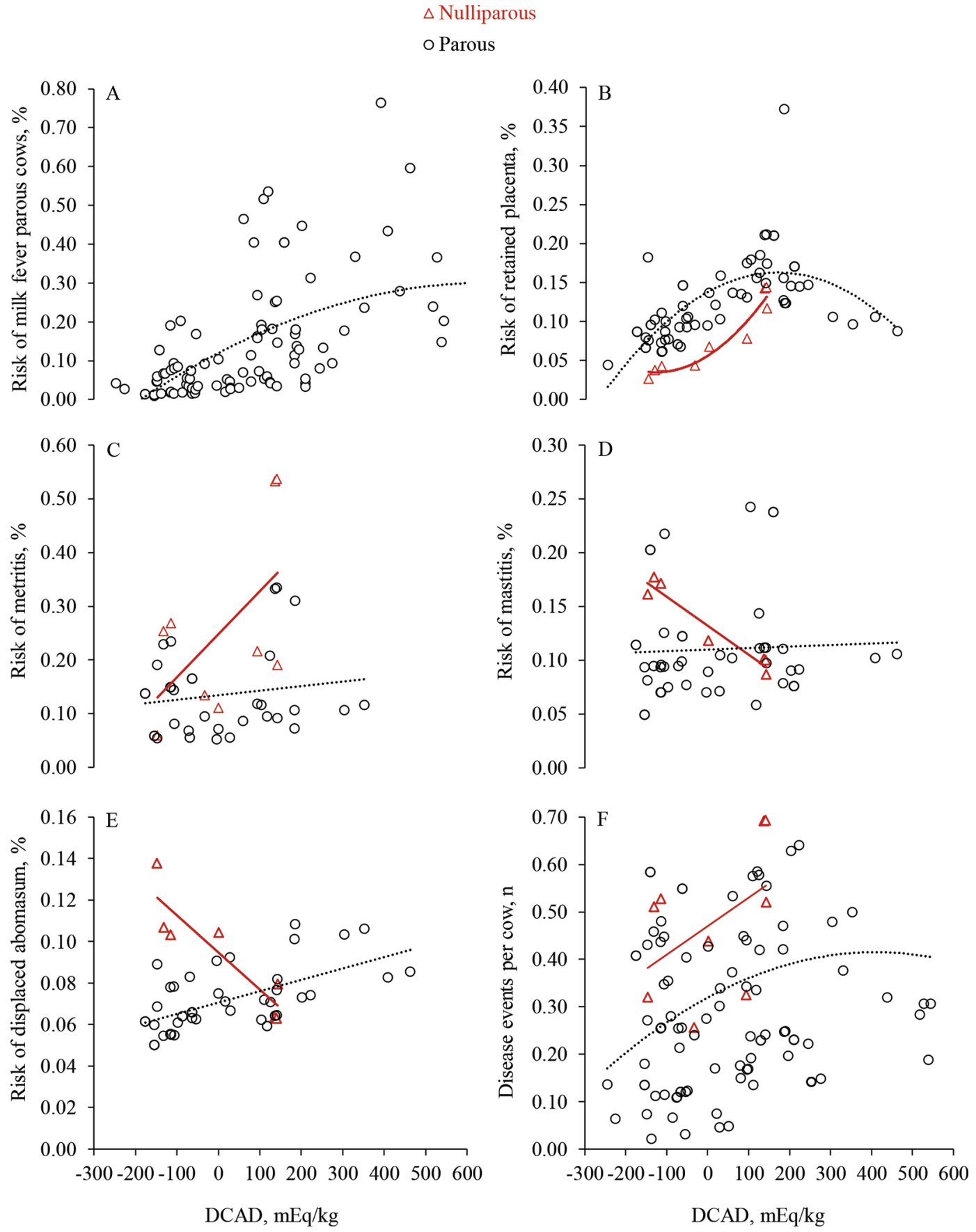

Figure 6. Risk of diseases (proportion of cows affected) postpartum in nulliparous (triangle) and parous cows (circle) according to prepartum DCAD fed. Milk fever $(\mathrm{A})$; effect of DCAD $(P<0.001)$ and quadratic effect of DCAD $(P<0.001)$. Retained placenta $(\mathrm{B})$; effect of DCAD $(P$ $<0.001)$, quadratic effect of DCAD $(P=0.05)$, parity $(P=0.12)$, and interaction between DCAD and parity $(P=0.59)$. Metritis $(\mathrm{C})$; effect of DCAD $(P=0.02)$, parity $(P=0.11)$, and interaction between DCAD and parity $(P=0.33)$. Mastitis $(\mathrm{D})$; effect of DCAD $(P=0.60)$, parity $(P=0.53)$, and interaction between DCAD and parity $(P=0.35)$. Displaced abomasum $(\mathrm{E})$; effect of DCAD $(P=0.68)$, parity $(P=0.48)$, and interaction between DCAD and parity $(P=0.45)$. Number of disease events per cow $(\mathrm{F})$; effect of DCAD $(P=0.002)$, quadratic effect of DCAD $(P<0.001)$, parity $(P=0.88)$, and interaction between DCAD and parity $(P=0.56)$. 
which might influence the ability of diets with negative DCAD to reduce the risk of milk fever.

We found no statistically significant associations between concentrations of dietary $\mathrm{P}$ or $\mathrm{Mg}$ and risk of milk fever and other peripartum diseases. Out of 134 treatment diets, 115 and 118 had concentrations of $\mathrm{P}$ and $\mathrm{Mg}$, respectively, within 0.20 and $0.50 \%$ of diet DM. It seems that, within that range of dietary feeding, these minerals have minor effects on risk of diseases or postpartum performance. Surprisingly, we found that increasing dietary $\mathrm{Mg}$ reduced blood tCa concentrations, but we found no indication that feeding diets with increased content of $\mathrm{Mg}$ reduced the risk of milk fever. Lean et al. (2006) showed that increasing dietary concentration of $\mathrm{Mg}$ from 0.2 to $0.6 \%$ was expected to reduce the incidence of milk fever from approximately 1.4 to $0.2 \%$. Surveys by the National Animal Health Monitoring System of the United States reported that $5 \%$ of all dairy cows are diagnosed with milk fever (NAHMS, 2007), which includes both primiparous and multiparous cows; however, when only multiparous cows were considered, incidence of milk fever increased from $4 \%$ in cows of lactation 2 to $13 \%$ in cows of lactation 6 (Reinhardt et al., 2011), resulting in a mean incidence in multiparous cows of $6.2 \%$ (Reinhardt et al., 2011). Several experiments in the meta-analysis used only cows starting lactation 3 and approximately $16.2 \%$ of the parous cows from experiments that reported milk fever were Jerseys, which are known to be more susceptible to milk fever; many treatments fed diets with positive DCAD. Therefore, it is not surprising that the incidence milk fever in the database of $11.2 \%$ was somewhat high, but within the expected given the groups of cows used and diets fed (NAHMS, 2007; Reinhardt et al., 2011).

Recommendations for concentrations of $\mathrm{Ca}, \mathrm{Mg}$, and $\mathrm{P}$ for prepartum cows fed acidogenic diets have not been extensively researched in typical dose-titration ex- periments. Diets with negative DCAD induced hypercalciuria, and, depending on dietary Ca intake, urinary Ca losses can increase from approximately 1 to $2 \mathrm{~g} / \mathrm{d}$ when fed alkalogenic diets to approximately 8 to $11 \mathrm{~g} / \mathrm{d}$ when fed acidogenic diets (Lopera et al., 2018; Rodney et al., 2018). Despite the increased urinary Ca loss, these cows maintain an estimated positive Ca balance of more than $10 \mathrm{~g} / \mathrm{d}$ in the last week of gestation when fed diets with 0.55 to $0.65 \%$ Ca (Lopera et al., 2018; Rodney et al., 2018). The early work by Ender et al. (1971) with cows fed alkalogenic or acidogenic diets in the last 2 wk of gestation and with intakes of $\mathrm{Ca}$ ranging from 30 to $150 \mathrm{~g} / \mathrm{d}$ showed no differences in prepartum Ca balance when cows consumed an average of $50 \mathrm{~g} / \mathrm{d}$ (Ca balance $+14 \mathrm{~g} / \mathrm{d}$ ) or $136 \mathrm{~g} / \mathrm{d}$ (Ca balance $+17 \mathrm{~g} / \mathrm{d}$ ). No cows fed the acidogenic diet developed milk fever (Ender et al., 1971) irrespective of Ca intake. Gelfert and Staufenbiel (2008) reviewed the literature and did not identify benefits of manipulating the dietary $\mathrm{Ca}$ content when cows were fed acidogenic diets prepartum. Therefore, there seems to be little or no justification to increasing dietary $\mathrm{Ca}$ above the needs to maintain a positive $\mathrm{Ca}$ balance prepartum. In fact, the current meta-analysis demonstrates a positive association between dietary Ca content and risk of milk fever, particularly in cows fed acidogenic diets.

Recommendations to increase dietary $\mathrm{Mg}$ to 0.35 to $0.50 \%$ of the diet DM (Lean et al., 2006; Goff, 2008) have been based on supplying additional $\mathrm{Mg}$ for increased gastrointestinal absorption, particularly paracellular transport. Magnesium is important for parathyroid hormone secretion and action (Vetter and Lohse, 2002) and bone Ca resorption (Robson et al., 2004), which creates a link between $\mathrm{Mg}$ and Ca metabolism. Allen et al. (1981) showed an association between blood Mg and hypocalcemia and cows with $\mathrm{Mg}$ below $0.80 \mathrm{~m} M$ had increased risk of milk fever. Despite the important role of $\mathrm{Mg}$ on $\mathrm{Ca}$ metabolism, we found little evidence of

Table 8. Effect of reducing the DCAD from +200 to $-100 \mathrm{mEq} / \mathrm{kg}$ on estimated incidence of diseases in Holstein cows according to parity group

\begin{tabular}{|c|c|c|c|c|c|c|c|}
\hline Item, $\% \pm$ SEM & $\begin{array}{l}\text { Means } \\
(\text { Exp. })^{1}\end{array}$ & \multicolumn{2}{|c|}{ Nulliparous } & \multicolumn{2}{|c|}{ Parous } & \multicolumn{2}{|r|}{$P$-value ${ }^{2}$} \\
\hline Milk fever, parous cow ${ }^{3}$ & $99(35)$ & 0 & 0 & $11.7 \pm 2.8$ & $2.8 \pm 0.9$ & $<0.001$ & $\mathrm{NE}^{4}$ \\
\hline Retained placenta ${ }^{3}$ & $73(22)$ & $12.7 \pm 2.7$ & $3.5 \pm 2.7$ & $17.0 \pm 1.6$ & $9.0 \pm 1.6$ & 0.001 & 0.61 \\
\hline Metritis & $42(12)$ & $34.4 \pm 5.6$ & $12.0 \pm 5.6$ & $16.3 \pm 2.7$ & $9.9 \pm 2.7$ & 0.02 & 0.34 \\
\hline Mastitis & $52(14)$ & $8.9 \pm 5.4$ & $16.7 \pm 5.4$ & $11.5 \pm 2.0$ & $9.4 \pm 2.0$ & 0.60 & 0.35 \\
\hline Displaced abomasum & $49(14)$ & $6.7 \pm 4.3$ & $11.9 \pm 4.3$ & $8.0 \pm 1.2$ & $6.6 \pm 1.2$ & 0.69 & 0.45 \\
\hline
\end{tabular}

${ }^{1}$ Number of treatment means and number of experiments (Exp.) that contributed with data for the analyses.

${ }^{2} \mathrm{DCAD}=$ linear effect of altering the DCAD; DCAD $\times$ parity $=$ interaction between the linear effect of altering the DCAD and parity $($ nulliparous or parous).

${ }^{3}$ Quadratic effect of DCAD $(P<0.05)$.

${ }^{4}$ Nonestimable because parity group was not included in the model for milk fever because of $0 \%$ incidence in nulliparous cows. 
increased dietary $\mathrm{Mg}$ benefiting blood concentrations of tCa, health, or production performance in dairy cows. Perhaps, response to $\mathrm{Mg}$ in reducing hypocalcemia is dependent upon the dietary content of $\mathrm{K}$, and the lack of effect of $\mathrm{Mg}$ on incidence of milk fever might be related to the low dietary $\mathrm{K}$ content of diets fed in many of the experiments. In parous cows, the median $\mathrm{K}$ content was $1.29 \%$ (i.e., half of the diets fed had less than $1.30 \% \mathrm{~K}$ ), which would reduce the needs for dietary Mg. Nevertheless, because estimated Mg balance in the last week of gestation can be negative, perhaps it is prudent to feed diets with additional $\mathrm{Mg}$, as recommended by others (Goff, 2008).

Finally, mice models have shown that increasing blood $\mathrm{P}$ is known to stimulate production and secretion of fibroblast growth factor 23 by osteoblasts and osteocytes (Liu and Quarles, 2007), and increasing dietary $\mathrm{P}$ content increases serum $\mathrm{P}$ concentration (Peterson et al., 2005). The role of fibroblast growth factor 23 is to regulate blood phosphate, but it also inhibits renal $1 \alpha$-hydroxylase, thereby suppressing the synthesis of 1,25-dihydroxyvitamin $\mathrm{D}_{3}$ (Liu and Quarles, 2007), which might affect $\mathrm{Ca}$ homeostasis. Review of Figures $5 \mathrm{~B}$ and $5 \mathrm{E}$ suggests that in experiments in which cows were fed diets with positive DCAD and high dietary $\mathrm{P}$, both blood tCa was lowest and incidence of milk fever was highest. In fact, the same figures show that increasing dietary $\mathrm{P}$ content numerically reduced blood tCa and numerically increased the risk of milk fever in diets with either positive or negative DCAD. This finding is consistent with Lean et al., (2006), who observed increased risk of milk fever with increased $\mathrm{P}$ content of prepartum diet. Peterson et al. (2005) fed prepartum parous Holstein cows mildly acidogenic diets $(-13$ to $-20 \mathrm{mEq} / \mathrm{kg}$ ) with $0.21,0.31$, or $0.44 \% \mathrm{P}$, resulting in daily $\mathrm{P}$ intakes of 34,48 , and $67 \mathrm{~g} / \mathrm{d}$, respectively, in the last $28 \mathrm{~d}$ of gestation. Feeding $0.21 \%$ dietary $\mathrm{P}$ resulted in the lowest concentrations of serum $\mathrm{P}$ prepartum; however, feeding a diet with $0.44 \% \mathrm{P}$ resulted in the lowest concentrations of serum tCa prepartum and on the day of calving. In fact, incidence of subclinical hypocalcemia on the day of calving numerically increased with increasing dietary $\mathrm{P}$, to 50,69 , and $75 \%$, for cows fed $0.21,0.31$, and $0.44 \%$, respectively. Production of ECM was numerically greater for cows fed 0.21 than $0.44 \% \mathrm{P}$ prepartum (Peterson et al., 2005). Recently, Cohrs et al. (2018) fed 18 Holstein cows prepartum diets with a positive DCAD and containing either 0.152 or $0.283 \%$ of the DM as P. Cows fed the very low dietary $\mathrm{P}(0.152 \%)$ had increased blood tCa around calving and none developed milk fever, whereas 3 of the 9 cows fed $0.283 \%$ dietary $\mathrm{P}$ developed milk fever. Therefore, although data are not conclusive to the exact level of dietary $\mathrm{P}$ to be fed, it seems prudent to limit the dietary content of $\mathrm{P}$ and avoid supplementation prepartum to minimize the risk of hypocalcemia.

\section{CONCLUSIONS}

Reducing the DCAD of diets fed to prepartum cows reduced DMI prepartum but increased postpartum intake. Parous cows produced more milk, FCM, fat, and protein when fed acidogenic diets prepartum, but a similar response was not observed in nulliparous cows. It is possible that the limited number of experiments reporting data on nulliparous precluded a more precise estimate of the effects of manipulating the DCAD on that group of cows. Reducing the DCAD reduced the incidence of milk fever in parous cows and the incidence of retained placenta and metritis in all cows. Given the available data, parous cows should be fed diets with negative DCAD, but they probably do not need to be smaller than $-150 \mathrm{mEq} / \mathrm{kg}$ of DM. Little to no effect was observed from manipulating the dietary contents of $\mathrm{Ca}, \mathrm{P}$, or $\mathrm{Mg}$ in prepartum diets, except that increasing dietary $\mathrm{Ca}$ tended to increase the risk of milk fever in parous cows, particularly in those fed diets with positive DCAD. These findings support the recommendation of feeding acidogenic diets to parous cows to improve Ca metabolism around calving, reduce the risk of milk fever and uterine diseases, and improve lactation performance. Important gaps were identified in the current literature, with a limited number of experiments with nulliparous cows or experiments in which concentrations of dietary $\mathrm{Ca}, \mathrm{P}$, or $\mathrm{Mg}$ were manipulated when cows were fed acidogenic diets. Further experiments are needed to clarify the effects of manipulating the DCAD in diets fed to nulliparous cows.

\section{ACKNOWLEDGMENTS}

The authors thank the researchers who provided detailed data not available in the published manuscripts. Financial support for this project was provided by Arm \& Hammer Animal Nutrition (Princeton, NJ).

\section{REFERENCES}

Al-Eknah, M. M., and D. E. Noakes. 1989. A preliminary study on the effect of induced hypocalcaemia and nifedipine on uterine activity in the parturient cow. J. Vet. Pharmacol. Ther. 12:237-239.

Allen, W. M., B. F. Sansom, and D. C. Davies. 1981. Hypomagnesaemia in cows. Vet. Rec. 109:342.

Block, E. 1984. Manipulating dietary anions and cations for prepartum dairy cows to reduce incidence of milk fever. J. Dairy Sci. 67:2939-2948.

Bluel, R. J. V. 2006. The effects of supplemental anionic salts \& yeast culture on the production of dairy cattle during the periparturient period. MS thesis. Department of Animal Sciences, University of Missouri, Columbia. Accessed May 4, 2017. https://mospace 
.umsystem.edu/xmlui/bitstream/handle/10355/4638/research.pdf ? sequence $=3 \&$ isAllowed $=y$.

Bodarski, R., S. Kinal, J. Preś, M. Słupczyńska, and J. Twardoń. 2013. The effect of $\mathrm{MgSO}_{4}$ addition and the increasing doses of calcium and phosphorus during ending drying period on the occurrence of hypocalcaemia and hypophosphataemia in dairy cows. Pol. J. Vet. Sci. 16:655-662.

Bondurant, R. H. 1999. Inflammation in the bovine female reproductive tract. J. Anim. Sci. 77(Suppl. 2):101-110.

Chan, P. S., J. W. West, and J. K. Bernard. 2006. Effect of prepartum dietary calcium on intake and serum and urinary mineral concentrations of cows. J. Dairy Sci. 89:704-713.

Charbonneau, E., D. Pellerin, and G. Oetzel. 2006. Impact of lowering dietary cation-anion difference in nonlactating dairy cows: A metaanalysis. J. Dairy Sci. 89:537-548.

Cohrs, I., M. R. Wilkens, and W. Grünberg. 2018. Short communication: Effect of dietary phosphorus deprivation in late gestation and early lactation on the calcium homeostasis of periparturient dairy cows. J. Dairy Sci. 101:9591-9598.

Cozzi, G., F. Dal Corobbo, A. Pesavento, L. Ravarotto, and G. Gabai. 2005. Effects of two different prepartum diets on some metabolic traits and productive response in multiparous Holstein cows in early lactation. Ital. J. Anim. Sci. 4:127-137.

Crnkic, C., S. Muratovic, S. Piplica, A. Kavazovic, and S. Kutlaca. 2010. Blood plasma mineral profile and health status in postpartum cows fed an anionic diet before parturition. Turk. J. Vet. Anim. Sci. 34:255-260.

Curtis, C. R., H. Erb, C. Sniffen, R. Smith, P. Powers, M. Smith, M. White, R. Hillman, and E. Pearson. 1983. Association of parturient hypocalcemia with eight periparturient disorders in Holstein cows. J. Am. Vet. Med. Assoc. 183:559-561.

DeGroot, M. A., E. Block, and P. D. French. 2010. Effect of prepartum anionic supplementation on periparturient feed intake, health, and milk production. J. Dairy Sci. 93:5268-5279.

Dishington, I. W. 1975. Prevention of milk fever (hypocalcaemia paresis puerperalis) by dietary salt supplements. Acta Vet. Scand. 16:503-512.

Drackley, J. K. 1999. Biology of dairy cows during the transition period: The final frontier? J. Dairy Sci. 82:2259-2273.

Drackley, J. K., and F. C. Cardoso. 2014. Prepartum and postpartum nutritional management to optimize fertility in high-yielding dairy cows in confined TMR systems. Animal 8(Suppl 1):5-14.

Ender, F., I. W. Dishington, and A. Helgebostad. 1971. Calcium balance studies in dairy cows under experimental induction or prevention of hypocalcaemia paresis puerperalis. Z. Tierphysiol. Tierernahr. Futtermittelkd. 28:233-256.

Ganjkhanlou, M., A. Nikkhah, and A. Zali. 2010. Effect of dietary cation-anion balance on milk production and blood mineral of Holstein cows during the last two months of pregnancy. Afr. J. Biotechnol. 9:5983-5988.

Gaynor, P. J., F. J. Mueller, J. K. Miller, N. Ramsey, J. P. Goff, and R. L. Horst. 1989. Parturient hypocalcemia in Jersey cows fed alfalfa haylage-based diets with different cation to anion ratios. J. Dairy Sci. 72:2525-2531.

Gelfert, C. C., and R. Staufenbiel. 2008. The role of dietary calcium concentration in the use of anionic salts to prevent parturient paresis in dairy cows. Berl. Munch. Tierarztl. Wochenschr. 121:256-262.

Goff, J. P., A. Liesegang, and R. Horst. 2014. Diet-induced pseudohypoparathyroidism: A hypocalcemia and milk fever risk factor. J. Dairy Sci. 97:1520-1528.

Goff, J. P. 2008. The monitoring, prevention, and treatment of milk fever and subclinical hypocalcemia in dairy cows. Vet. J. 176:50-57.

Goff, J. P., and R. L. Horst. 1997. Effects of the addition of potassium or sodium, but not calcium, to prepartum rations on milk fever in dairy cows. J. Dairy Sci. 80:176-186.

Goff, J. P., and R. L. Horst. 1998. Use of hydrochloric acid as a source of anions for prevention of milk fever. J. Dairy Sci. 81:2874-2880.

Goff, J. P., R. L. Horst, F. J. Mueller, and J. K. Miller. 1991. Addition of chloride to a prepartal diet high in cations increases 1,25-dihy- droxyvitamin D response to hypocalcemia preventing milk fever. J. Dairy Sci. 74:3863-3871.

Grünberg, W., S. S. Donkin, and P. D. Constable. 2011. Periparturient effects of feeding a low dietary cation-anion difference diet on acidbase, calcium, and phosphorus homeostasis and on intravenous glucose tolerance test in high-producing dairy cows. J. Dairy Sci. 94:727-745.

Gulay, M. S., M. J. Hayen, K. C. Bachman, and H. H. Head. 2008. Prepartum feeding of cationic or anionic diets to Holstein cows given 30 or 60 day dry periods: Comparison of dry matter intake, physiological measures and milk production. Asian-Aust. J. Anim. Sci. 21:83-89.

Joyce, P. W.. W. K. Sanchez, and J. P. Goff. 1997. Effect of anionic salts in prepartum diets based on alfalfa. J. Dairy Sci. 80:28662875 .

Kichura, T. S., R. L. Host, D. C. Beitz, and E. T. Littledike. 1982. Relationships between prepartal dietary calcium and phosphorus, vitamin D metabolism, and parturient paresis in dairy cows. J. Nutr. 112:480-487.

Kimura, K., T. A. Reinhardt, and J. P. Goff. 2006. Parturition and hypocalcemia blunts calcium signals in immune cells of dairy cattle. J. Dairy Sci. 89:2588-2595.

Kocabağli, N., R. Kahraman, I. Abas, H. Eseceli, and M. Alp. 2001. The effects of supplemental anionic salts and probiotic in prepartum diets on milk production and quality and incidence of milk fever in dairy cows. Turk. J. Vet. Anim. Sci. 25:743-751.

Kronqvist, C., U. Emanuelson, R. Spörndly, and K. Holtenius. 2011. Effects of prepartum dietary calcium level on calcium and magnesium metabolism in periparturient dairy cows. J. Dairy Sci. 94:1365-1373.

Lean, I. J., P. DeGaris, D. McNeil, and E. Block. 2006. Hypocalcemia in dairy cows: Meta-analysis and dietary cation anion difference theory revisited. J. Dairy Sci. 89:669-684.

Lean, I. J., P. J. DeGaris, P. Celi, D. M. McNeill, R. M. Rodney, and D. R. Fraser. 2014. Influencing the future: Interactions of skeleton, energy, protein and calcium during late gestation and early lactation. Anim. Prod. Sci. 54:1177-1189.

Leclerc, H., and E. Block. 1989. Effects of reducing dietary cationanion balance for prepartum dairy cows with specific reference to hypocalcemic parturient paresis. Can. J. Anim. Sci. 69:411-423.

Lema, M., W. B. Tucker, M. Aslam, I. S. Shin, P. Le Ruyet, and G. D. Adams. 1992. Influence of calcium chloride fed prepartum on severity of edema and lactational performance of dairy heifers. J. Dairy Sci. 75:2388-2393.

Leno, B. M., S. E. LaCount, C. M. Ryan, D. Briggs, M. Crombie, and T. R. Overton. 2017b. The effect of source of supplemental dietary calcium and magnesium in the peripartum period, and level of dietary magnesium postpartum, on mineral status, performance, and energy metabolites in multiparous Holstein cows. J. Dairy Sci. 100:7183-7197.

Leno, B. M., C. M. Ryan, T. Stokol, D. Kirk, K. P. Zanzalari, J. D. Chapman, and T. R. Overton. 2017a. Effects of prepartum dietary cation-anion difference on aspects of peripartum mineral and energy metabolism and performance of multiparous Holstein cows. J. Dairy Sci. 100:4604-4622.

Liu, S., and L. D. Quarles. 2007. How fibroblast growth factor 23 works. J. Am. Soc. Nephrol. 18:1637-1647.

Lopera, C., R. Zimpel, A. Vieira-Neto, F. R. Lopes, W. Ortiz, B. N. Faria, M. L. Gambarini, M. Poindexter, E. Block, C. D. Nelson, and J. E. P. Santos. 2018. Effects of level of dietary cation-anion difference and duration of prepartum feeding on performance and metabolism of dairy cows. J. Dairy Sci. 101:7907-7929.

Martín-Tereso, J., H. ter Wijlen, H. van Laar, and M. W. A. Verstegen. 2014. Peripartal calcium homoeostasis of multiparous dairy cows fed rumen-protected rice bran or a lowered dietary cation/ anion balance diet before calving. J. Anim. Physiol. Anim. Nutr. (Berl.) 98:775-784

Martinez, N., C. A. Risco, F. S. Lima, R. S. Bisinotto, L. F. Greco, E. S. Ribeiro, F. P. Maunsell, K. N. Galvão, and J. E. P. Santos. 2012. Evaluation of peripartal calcium status, energetic profile, 
and neutrophil function in dairy cows at low or high risk of developing uterine disease. J. Dairy Sci. 95:7158-7172.

Martinez, N., R. M. Rodney, E. Block, L. L. Hernandez, C. D. Nelson, I. J. Lean, and J. E. P. Santos. 2018a. Effects of prepartum dietary cation-anion difference and source of vitamin D on dairy cows: Lactation performance and energy metabolism. J. Dairy Sci. 101:2544-2562.

Martinez, N., R. M. Rodney, E. Block, L. L. Hernandez, C. D. Nelson, I. J. Lean, and J. E. P. Santos. 2018b. Effects of prepartum dietary cation-anion difference and source of vitamin D on dairy cows: Health and reproductive responses. J. Dairy Sci. 101:2563-2578.

Martinez, N., L. D. Sinedino, R. S. Bisinotto, E. S. Ribeiro, G. C. Gomes, F. S. Lima, L. F. Greco, C. A. Risco, K. N. Galvão, D Taylor-Rodriguez, J. P. Driver, W. W. Thatcher, and J. E. P. Santos. 2014. Effect of induced subclinical hypocalcemia on physiological responses and neutrophil function in dairy cows. J. Dairy Sci. 97:874-887.

Moher, D., A. Liberati, J. Tetzlaff, and D. G. Altman. 2009. The PRISMA Group. Preferred reporting items for systematic reviews and meta-analyses: The PRISMA statement. PLoS Med. 6:e1000097.

Moore, S. J., M. J. VandeHaar, B. K. Sharma, T. E. Pilbeam, D. K. Beede, H. F. Bucholtz, J. S. Liesman, R. L. Horst, and J. P. Goff. 2000. Effects of altering dietary cation-anion difference on calcium and energy metabolism in peripartum cows. J. Dairy Sci. 83:2095-2104.

Morrill, K. M., S. P. Marston, N. L. Whitehouse, M. E. Van Amburgh, C. G. Schwab, D. M. Haines, and P. S. Erickson. 2010. Anionic salts in the prepartum diet and addition of sodium bicarbonate to colostrum replacer, and their effects on immunoglobulin G absorption in the neonate. J. Dairy Sci. 93:2067-2075.

National Animal Health Monitoring System (NAHMS). 2007. Dairy 2007-Part I: Reference of dairy cattle health and management practices in the United States. USDA Animal and Plant Health Inspection Service. Accessed Jan. 10, 2018. https://www.aphis.usda .gov/aphis/ourfocus/animalhealth/monitoring-and-surveillance/ nahms/nahms_dairy_studies.

Oetzel, G. R. 1991. Meta-analysis of nutritional risk factors for milk fever in dairy cattle. J. Dairy Sci. 74:3900-3912.

Oetzel, G. R., J. D. Olson, C. R. Curtis, and M. J. Fettman. 1988. Ammonium chloride and ammonium sulfate for prevention of parturient paresis in dairy cows. J. Dairy Sci. 71:3302-3309.

Penner, G. B., G. F. Tremblay, T. Dow, and M. Oba. 2008. Timothy hay with a low dietary cation-anion difference improves calcium homeostasis in periparturient Holstein cows. J. Dairy Sci. 91:1959-1968

Peterson, A. B., M. W. Orth, J. P. Goff, and D. K. Beede. 2005. Periparturient responses of multiparous Holstein cows fed different dietary phosphorus concentrations prepartum. J. Dairy Sci. 88:3582-3594.

Puntenney, S. B. 2006. The effect of prepartum anionic diets on cortisol, adiponectin, and tumour necrosis factor- $\alpha$ expression at varying levels of body mass index in preparturient dairy cows: Implications for insulin resistance. PhD Dissertation, Department of Animal Sciences, Oregon State University, Corvallis. Accessed May 4, 2017. https://ir.library.oregonstate.edu/concern/graduate _thesis_or_dissertations/th83m3366.

Ramberg, C. F., G. Mayer, D. Kronfeld, J. Phang, and M. Berman 1970. Calcium kinetics in cows during late pregnancy, parturition, and early lactation. Am. J. Physiol. 219:1166-1177.

Ramos-Nieves, J. M., B. J. Thering, M. R. Waldron, P. W. Jardon, and T. R. Overton. 2009. Effects of anion supplementation to lowpotassium prepartum diets on macromineral status and performance of periparturient dairy cows. J. Dairy Sci. 92:5677-5691.

Razzaghi, A., H. Aliarabi, M. M. Tabatabaei, A. A. Saki, R. Valizadeh, and P. Zamani. 2012. Effect of dietary cation-anion difference during prepartum and postpartum periods on performance, blood and urine minerals status of Holstein dairy cow. Asian-Australas. J. Anim. Sci. 25:486-495.

Reinhardt, T. A., J. D. Lippolis, B. J. McCluskey, J. P. Goff, and R. L. Horst. 2011. Prevalence of subclinical hypocalcemia in dairy herds. Vet. J. 188:122-124.

Rérat, M., A. Philipp, H. D. Hess, and A. Liesegang. 2009. Effect of different potassium levels in hay on acid-base status and mineral balance in periparturient dairy cows. J. Dairy Sci. 92:6123-6133.

Rérat, M., and P. Schlegel. 2014. Effect of dietary potassium and anionic salts on acid-base and mineral status in periparturient cows. J. Anim. Physiol. Anim. Nutr. (Berl.) 98:458-466.

Rezac, D. J., E. Block, D. Weber, M. J. Brouk, and B. J. Bradford. 2014. Effects of prepartum dietary cation-anion difference and acidified coproducts on dry matter intake, serum calcium, and performance of dairy cows. J. Anim. Sci. 92:666-675.

Robalo Silva, J., and D. E. Noakes. 1984. The effect of experimentally induced hypocalcaemia on uterine activity at parturition in the ewe. Theriogenology 21:607-623.

Robson, A. B. A. R. Sykes, A. E. McKinnon, and S. T. Bel. 2004. A model of magnesium metabolism in young sheep: Transactions between plasma, cerebrospinal fluid and bone. Br. J. Nutr. 91:73-79.

Rodney, R. M., N. Martinez, E. Block, L. L. Hernandez, P. Celi, C. D. Nelson, J. E. P. Santos, and I. J. Lean. 2018. Effects of prepartum dietary cation-anion difference and source of vitamin D in dairy cows: Vitamin D, mineral, and bone metabolism. J. Dairy Sci. 101:2519-2543.

Rodriguez-Suarez, L. A. 1998. Periparturient responses of cows fed varying dietary cation-anion differences and calcium contents prepartum. PhD Dissertation, Department of Animal Sciences, Michigan State University, East Lansing.

Stockdale, C. R. 2004. Effects of feeding magnesium sulfate to dry pregnant dairy cows with different body condition scores on intake in late gestation, periparturient blood calcium concentrations and production in early lactation. Aust. J. Exp. Agric. 44:539-546.

Tucker, W. B., J. F. Hogue, G. D. Adams, M. Aslam, I. S. Shin, and G. Morgan. 1992. Influence of dietary cation-anion balance during the dry period on the occurrence of parturient paresis in cows fed excess calcium. J. Anim. Sci. 70:1238-1250.

Vagnoni, D. B., and G. R. Oetzel. 1998. Effects of dietary cationanion difference on the acid-base status of dry cows. J. Dairy Sci. 81:1643-1652.

Vetter, T., and M. J. Lohse. 2002. Magnesium and the parathyroid. Curr. Opin. Nephrol. Hypertens. 11:403-410.

Wang, M., and B. J. Bushman. 1999. Integrating Results Through Meta-Analytic Review Using SAS Software. SAS Institute Inc., Cary, NC

Weich, W., E. Block, and N. B. Litherland. 2013. Extended negative dietary cation-anion difference feeding does not negatively affect postpartum performance of multiparous dairy cows. J. Dairy Sci. 96:5780-5792.

Wu, W. X., J. X. Liu, G. Z. Xu, and J. A. Ye. 2008. Calcium homeostasis acid-base balance, and health status in periparturient Holstein cows fed diets with low cation-anion difference. Livest. Sci. 117:7-14.

Wu, Z., J. K. Bernard, and S. J. Taylor. 2015. Effect of feeding calcareous marine algae to Holstein cows prepartum or postpartum on serum metabolites and performance. J. Dairy Sci. 98:4629-4639.

Wu, Z., J. K. Bernard, K. P. Zanzalari, and J. D. Chapman. 2014 Effect of feeding a negative dietary cation-anion difference diet for an extended time prepartum on postpartum serum and urine metabolites and performance. J. Dairy Sci. 97:7133-7143.

Zimpel, R., M. B. Poindexter, A. Vieira-Neto, E. Block, C. R. Staples, W. W. Thatcher, and J. E. P. Santos. 2018. Effect of dietary cation-anion difference on acid-base status and dry matter intake in dry cows. J. Dairy Sci. 101:8461-8475. 